Celestinesca 33 (2009): 275-320 https://doi.org/10.7203/Celestinesca.33.20102

\title{
Celestina: Documento bibliográfico (suplemento número 31)
}

\author{
Joseph T. Snow \\ Michigan State University (Emeritus)
}

[El trigésimo suplemento bibliográfico apareció en el tomo 30 (2006), continuando una serie que inicié en 1985. El que debió aparecer en 2007 nunca llegó a completarse y se pospuso. La necesidad en 2008 de usar todo el espacio para la publicación de las actas del simposio sobre $\mathrm{Ce}$ lestina de Lyon hizo que sólo ahora, en 2009, aparezca este suplemento, evidentemente algo extendido por la recuperación de los estudios llevados a cabo desde el trigésimo (más de 200 entradas). He tenido la ayuda de los profesores Eloísa Palafox que me dejó los materiales que tenía (sin anotar) y Raúl Álvarez que contribuyó con cuatro de las anotaciones de este suplemento (marcados al final: [RA]). A los dos mis más sinceras gracias. También me han proporcionado, generosamente, materiales reseñados en este suplemento: P. Botta, F. Carmona, E. Fernández, C. Heusch, J. Maestro y C. Scarborough. No hubo tiempo para anotar unas cuantas cosas, que dejo a mi sucesor, Devid Paolini, para un futuro suplemento. Una cosa notable en este suplemento es la gran cantidad de entradas bajo ROJAS: ediciones, reimpresiones, traducciones, adaptaciones de varios tipos y nuevos formatos para apreciar la obra, muchas de ellas con ilustraciones originales. JTS.

1856. ALARCOS, Miguel, «La bella de Fernando de Rojas: innovación y tradición ovidiana", Archivo de Filología Aragonesa 59-60 (2002-2004), 1757-1772.

Compara sutílmente la descripción de Melibea en el Auto I, punto por punto, con los antecedentes en Juan Ruiz y Ovidio para concluir que 
Rojas rehace la «bella» de Juan Ruiz, agregando huellas ovidianas por él rechazados y, al final, creando una descripción caracterizadora del que describe, exagerada hasta la caricatura.

1857. ALBALÁ PELEGRÍN, Marta, "Un códice misceláneo: la Comedia de Calisto y Melibea, Sevilla, 1501, Rès Yg. 63, BNF», Bulletin of Spanish Studies 86.4 (junio 2009), 435-58.

El único ejemplar de la Comedia de 1501 (en París) es facticio. Contiene al final once rondeaux franceses contemporáneos de la Comedia que se editan aquí por primera vez en un apéndice. El estudio especula sobre sus dueños previos, sus encuadernaciones y el por qué de estar unidos estos textos en un único tomo; lo más probable, como se demuestra en un agudo análisis, es que los temas de amor cortés en una obra y otra se asemejaban para el dueño que los unió.

1858. ALONSO ASENJO, Julio, "El nigromante en el teatro prelopista", en Comedias y comediantes. Estudios sobre el teatro clásico español, ed. M. V. Diago \& T. Ferrer (Collecció Oberta, Valencia: Universidad - Dept. de Filologia Espanyola, 1991), 91-105.

En el segundo apartado, se habla brevemente de Celestina y de obras celestinescas como la Tragedia Policiana (1547), la Comedia Eufrosina (1542), la Comedia Tidea (1550), la Comedia Florinea (1554), y la Comedia Selvagia (1554). No ofrece detalles ni comparaciones con las artes de Celestina (pp. 97-98).

1859. ÁlVAREZ MORENO, Raúl, "Religious Struggle, Linguistic Struggle: Exposing the Challenge to the Transcendental in Celestina», eHumanista vol.12 (2009), 182-201. (www.ehumanista.ucsb.edu)

En la segunda mitad del s. Xv, la evolución desde lo transcendental hacia lo particular, visible y material, dio lugar a nuevas formulaciones lingüísticas y religiosas que aquí se estudian en Celestina. El triple análisis de "Dios», «de Dios" y «a Dios» lo evidencia claramente, como los ejemplos aducidos lo comprueban plenamente. Y es que la relación entre res y verba había sido reexaminada en un mundo nuevamente invadido por la multiplicidad, la ambigüedad y un concepto de tiempo más lineal que permite el control humano.

1860. ASENJO GONZÁLEZ, María, "La historia y la sociedad urbana en la lectura de La Celestina», Celestinesca 32 (2008), 13-36.

Lee Celestina por el interés que la obra suscita en cuanto a las muchas transformaciones sociales y urbanas a finales del siglo XV (vida religiosa y laica, articulación social, los distintos espacios urbanos y el caso de las clases marginadas). 
1861. AVALLE ARCE, J. B. de, Las novelas y sus narradores. Alcalá de Henares: Centro de Estudios Cervantinos, 2006.

Atribuye carácter narrativo a Celestina (novela dialogada) no por su forma dramática, que carece de narrador, pero por los preliminares en los que se ven una serie de autores, uno llenando las líneas establecidas por otro (auto I). Uno de los aciertos de esta obra de final estoico es la inclusión de los padres de Melibea y, en particular a Pleberio, cuya presencia subraya y engrandece el mensaje. Ver el Índice.

1862. BARANDA, Consolación, y Ana Ma VIÁN HERRERO, «El nacimiento crítico del 'género' celestinesco: Historia y perspectivas», en "Orígenes de la novela». Estudios, dir. R. Gutiérrez Sebastián \& B. Rodríguez Gutiérrez (Santander: Universidad de Cantabria/Sociedad Menéndez Pelayo, 2007), 407-481.

Estas dos reconocidas celestinistas consideran en profundidad las aportaciones esenciales de Menéndez y Pelayo en la formulación del género y del corpus de lo que llamamos 'lo celestinesco' en el siglo XVI (1513-1602). Luego empalman sus ideas básicas con otras aportaciones sucesivas (Lida de Malkiel, Heugas, Whinnom y Baranda) en el campo metodológico. Señalan la larga influencia de Celestina y, en un alarde bibliográfico, resumen la situación actual de los estudios de la obras del género celestinesco (448-468). Terminan con unas sugerencias para revalorar tantas obras poco conocidas como el género al que pertenecen.

1863. BARANDA LETURIO, Nieves, "El lector en su tiempo: Marginalia a la Tragedia de Calisto y Melibea (Zaragoza 1507)", en 'Ad amica amicissime scripta': Homenaje a la profesora $M^{a}$ José López de Ayala y Genovés Coord. J. Costas Rodríguez (Madrid: UNED, 2005), vol. II: 191-200.

El único ejemplar completo de Zaragoza 1507 contiene marginalias de tres manos diferentes, algunas mutiladas con la encuadernación en un volumen facticio. Muchas de ellas se pueden resolver mediante distintas metodologías. Nos proporciona un caso interesante sobre la recepción casi coetánea con la publicación de la obra, en que los autores de las anotaciones tratan a Celestina como obra clásica más que una obra de diversión. Es evidente que tanto los autores del texto como los de estas anotaciones marginales practican la técnica de la memoria pulsada, característica de la enseñanza memorizada común a esa época.

1864. BAUTISTA, Francisco, «Realidad social e ideología en La Celestina», Celestinesca 32 (2008), 37-50.

Una cuidada consideración sobre las nociones que atribuyen al texto celestinesco un enfoque anti-nobiliario (Maravall y otros). Pero des- 
pués de citar comentarios de varios textos de la época sobre la nobleza, virtud, amor cortés y más, opta por indicar un carácter más bien estético-literario en los textos celestinescos (de Areúsa en el auto IX, de Sempronio en el auto II) con poco engarce con los temas políticos discutidos en el momento de su aparición.

1865. BEARDSLEY, Theodore S. Jr., "Early Editions of Celestina at the Hispanic Society of America», en La Celestina 1499-1999: 7-17.

Describe con detalle la cronología de las Celestinas en las colecciones de The Hispanic Society of America (HSA) de 1904 hasta 1999, con mención de las personalidades y las anécdotas relevantes a las distintas adquisiciones. En 1999, la HSA poseía 32 ediciones tempranas (11 de ellas son únicas) y otras ediciones en microfilm, varias traducciones $y$ unas cuantas ediciones facsimilares.

1867. BECERRA MAYOR, David, «El impacto burgués y la ambigüedad de los linajes de Melibea y Calisto", Verba Hispanica 14 (2006), 21-37.

Según esta lectura de la obra, el texto está lleno de contradicciones, confusiones y ambigüedades en la instancia de la vida social retratada. La transparencia del feudalismo se transforma en la libertad de la nueva burguesía y los primeros brotes del sistema capitalista, dando como resultado una sociedad en la que nadie sabe quién es realmente. Esta burguesía de Celestina está en un proceso de legitimarse creando nuevos hitos categorizadores. Sugiere que los protagonistas no se casan porque buscan el amor que existe sólo fuera del matrimonio.

1868. BELTRÁN, Rafael, «Lágrimas de Celestina suben del corazón a los ojos: imágenes poéticas en la 'memoria del buen tiempo' (Auto IX)", en Late Medieval Spanish Studies in Honour of Dorothy Sherman Severin, ed. J. T. Snow \& R. Wright (Liverpool: Liverpool UP, 2009), 159-169.

Es un estudio amplio de las razones por las cuales llora Celestina en el auto IX, una mezcla de análisis textual y el aprovechamiento de imágenes poéticas del siglo XV relacionadas con la noria (cuyos arcaduces suben llenos y bajan vacíos) y con el dolor de la memoria de mejores tiempos (Celestina recordando la honra de hace veinte años, ahora casi esfumada). Las citas de antecedentes y el análisis enriquecen la escena, con la incomprensión tanto de Areúsa como de Sempronio, anclados ambos en el momento presente.

1869. BERNALDO DE QUIRÓS MATEO, José Antonio, «Sobre el papel de Rojas en la elaboración de La Celestina», Lemir 12 (2008), 325-339.

En un comentario bien pensado y completo, expone los valores de la hipótesis de García Valdecasas (2000) de que Rojas interviene en la 
obra sólo hacia el final, trabajando con un texto completo, agregando sentencias y otras adiciones. Podría ser autor de los autos XV-XXI. Se apoya con las ideas de otros críticos como Canet (2007), Snow (20052006) Cantalapiedra $(1986,2000)$ y Sánchez-Serrano y Prieto de la Iglesia $(1989,2001)$. Termina reclamado una edición diferente de la obra más a tono con lo que sería la obra sobre la cual trabajó Rojas.

1870. BERNALDO DE QUIRÓS MATEO, José Antonio, «La Celestina desde el punto de vista escénico: Consecuencias para la atribución de la autoría», Lemir 13 (2009), 97-108.

Contrasta las técnicas escénicas de la obra y encuentra que las de los autos I-XIV distan mucho de las de los autos XV-XVI (de la Comedia de Calisto y Melibea). Estos datos apoyan las ideas de García Valdecasas (2000) de que Rojas sólo terminó la CCM y los primeros 14 autos eran de un autor anónimo. Hay muchos ejemplos aclaratorios para justificar esta dicotomía de artes escénicas.

1871. BIZZARRI, Hugo O., "Los refranes de Celestina interpretados por su 'primer comentarista'», Celestinesca 31 (2007), 9-22.

En este estudio se profundiza en la relación de los comentarios del autor anónimo de Celestina comentada y su relación con el studia humanitatis, todo al servicio de revelar su concepción de la lengua castellana. Presta atención especial a giros, etimologías, comparaciones de la lengua latina con la castellana, y la idea de Celestina como obra clásica. $\mathrm{Su}$ forma de ver las cosas difiere mucho de la forma de interpretar las paremias en obras como el Seniloquium (anón.) o la Philosophia vulgar de Mal Lara.

1872. BIZZARRI, Hugo O., "Celestina y la 'copia de sentencias entretejidas'», Celestinesca 32 (2008), 51-68.

Se centra en la presencia de "colligir flores» por Melibea (Auto xx) de los libros de Pleberio, un proceso interno que refleja la evolución de Rojas al absorber la gran copia de sentencias del antiguo autor. Posteriormente, esta búsqueda se explora externamente medinte tres facetas: en el lector humanista del ejemplar de Zaragoza 1507 (ahora en Toledo), en el anónimo comentarista humanista del texto de hacia 1570, y en Kaspar von Barth (1624, su traducción al latín).

1873. BLECUA, Alberto, "'Minerua con el can', o los falsos problemas filológicos», Revista de literatura medieval 14.1 (2002), 37-46.

Propone como lectura original de "Minerva con el can» (postulando seis manuscritos intermediarios) la frase "Semiramis con el caua- 
llo» (que llegaría al quinto intermediario - el Ms de Palacio- como «mjreua con el can»).

1874. BLINI, Leonardo, «La Tragicomedia en verso de Juan Sedeño (1540) y sus relaciones con ediciones anteriores de La Celestina», Lemir 13 (2009), 133-168.

Esta entrada y la siguiente tienen su origen en la tesis doctoral (Roma, 1988-1989) del autor, que ahora ve la luz. Blini, analizando la fidelidad léxica de Sedeño, se interesa en saber qué edición podría haber sido la base de la obra versificada. Utilizando fragmentos textuales y contrastándolos con las ediciones anteriores a 1520, primero, y con las restantes hasta 1540, después, descubre que ninguna ha podido servir de base, aunque hay correspondencias interesantes con el grupo de textos valencianos de 1514-1519-1529 (teoría avanzada primero por M. Marciales). También sugiere que, en el stemma presentado por Lobera, hubo un subarquetipo de las ediciones valencianas que bien podría haber sido el texto base de Sedeño, hoy perdido pero producto de la primera década del s. XVI.

1975. BLINI, Leonardo (ed.), Juan Sedeño. Tragicomedia de Calisto y Melibea. Nueuamente trobada y sacada de prosa en metro castellano por- (Salamanca, 1540). Lemir 13 (2009), Textos, pp. 29-234.

Blini presenta su estudio introductorio (pp. 31-46) y los criterios de edición con ilustraciones de los ejemplares consultados (Madrid, Nueva York, Austria), y una completa transcripción en formato de dos columnas (pp. 49-225), con notas textuales (pp. 226-233). La única edición es de Salamanca: Pedro de Castro, 1540.

1876. BOTTA, Patrizia, "En el texto de B», en La Celestina 1499-1999, 19-40.

Es este un minucioso estudio sobre el lugar único de la edición de Burgos 1499 en el stemma de las tres comedias (errores comunes, no comunes, lecciones superiores e inferiores, por ejemplo) que demuestra que una buena edición moderna debe basarse en la de Burgos, con las debidas correcciones.

1877. BOTTA, Patrizia, "Los epígrafes de La Celestina», en De rúbricas ibéricas, ed. A. Garribba (Col. Terra Ibérica II, Ricerca 1, Roma: Aracne, 2008), 183-208.

Reimpresión del artículo con el mismo título aparecido en 1999.

1878. BOTTA, Patrizia, "Entre cancionero, romancero, Celestina y Valencia", en Late Medieval Spanish Studies in Honour of Dorothy Sherman 
Severin, ed. J. T. Snow \& R. Wright (Liverpool: Liverpool UP, 2009), 104-113.

Edita el romance (en 80 octosílabos) del corrector de la Comedia, Alonso de Proaza, "en loor de la cibdad de Valencia» y un villancico (con 19 octosílabos) en forma de oración. Interesante también por las notas biográficas de Alonso de Proaza, que llama probable «colega» de Rojas en Salamanca.

1879. BOTTA, Patrizia, "Textos en devenir», en Autour de "La Celestina", ed. Rica Amran (Amiens: Univ. Picardie Jules Verne-Indigo, 2008), 267-280.

Botta puntualiza cómo el texto moderno (utiliza la edición de Russell, 1991) se configuró a través de varias etapas desde el MS a la edición de 22 autos (1526) y cómo se distinguen - tipográficamente-las distintas etapas en modernas ediciones. Imprime una lista de 90 ediciones impresas (y dos MSS) de Celestina (1499-1644) y describe en general las fases de su crecimiento. En las ediciones modernas, no leemos el texto como fue creado, sino sinópticamente (todas las fases en una edición combinada).

1880. BRIESEMEISTER, Dietrich, Spanien aus deutscher Sicht. DeutscheSpanische Kulturbeziehungen Gestern und Heute, ed. H. Wentzlaff-Eggebert. Beiheften zur Iberoromania, Tubingen: Max Niemeyer, 2004.

Contiene dos breves artículos sobre Celestina: (1) «Die lateinische Celestina. Kommentar und Übersetzung von Kaspar von Barth (1587-1658)», es una versión alemana de su estudio en castellano de 1998, "La Celestina latina. Comentario y versión humanista de Kaspar von Barth» (pp. 290-295); y (2) «Christoph Wirsungs deutschen Celestina-Übersetzungen (1520 und 1534)", que reimprime de la nota publicada en 1974 en Sprach, Literatur, Kultur, un libro de homenaje editado por él (aquí, pp. 296-301).

1881. CACHO CASAL, Rodrigo, "Marca Tulia se llamaba una dueña: la vieja consejera en la poesía burlesca del Siglo de Oro», Criticón 100 (2007), 71-90.

Las elegías ovidianas de Amores, con otras de Propercio, mediante el procedimiento del humanismo - la imitatio - han pasado por Celestina a tres autores de Renacimiento y Barroco: Diego Hurtado de Mendoza ("Hay una, quien quisiere saber de ella»), Quevedo (con tres romances estudiados) y Jacinto Alonso Maluenda («Romance a una taimada vieja»), todas ellas basadas en los consejos de Dipsas a una joven, con bastante exageración de lo grotesco y, más tarde, un humor fuertemente conceptista. 
1882. CANAVAGGIO, Jean, "La Célestine au miroir du théâtre espagnol des Xvie et Xvile siècles», Celestinesca 32 (2008), 69-84.

Sin negar la popularidad de aspectos de Celestina en obras teatrales de los siglos XVI y xVII, afirma que se ve más en el uso de refranes y sentencias y en referencias a los personajes y menos en estructuras y situaciones plagiadas (los ejemplos vienen de Lope y su escuela), siempre con la excepción de figuras de la madre Celestina. En la "comedia nueva» propuesta por Lope, la mezcla de lo cómico y lo trágico se rige por otras convenciones afectadas por la presencia del espectador.

1883. CANET VALLÉS, José Luis, "Celestina 'sic et non'. ¿Libro escolar universitario?», Celestinesca 31 (2007): 23-58.

Defiende la idea de que, específicamente, en la Universidad de Salamanca, y con un auditorio de escolares, nació Celestina, libro de texto, con un interés en fomentar una serie de reformas en el currículo y en la enseñanza. Además, sugiere la probabilidad de que sea el editor de la obra impresa Alonso de Proaza.

1884. CANET VALLÉS, José Luis, "Género y dramaturgia en la Celestina», Theatralia 10 (2008), 27-42.

Repasa los orígenes de Celestina, los terencianos y los basados en la comedia humanística, señalando aspectos comunes con estos textos $y$, al mismo tiempo, remarcando las innovaciones, tildando el complejo total no de 'teatral' sino de 'dramático'. Comenta cómo la obra dio origen a muchas obras teatrales posteriores, ejemplificadas en estas páginas por dos obras de Pedro Manuel de Urrea, su Égloga de Calisto y Melibea (1513) y la Penitencia de amor (1514).

1885. CANET VALLÉS, José Luis (ed.), La Comedia Thebayda. Textos Recuperados 21, Salamanca: Universidad, 2003.

En el largo estudio introductorio sobre la comedia humanística como antecedente de la Thebayda (primera imitación celestinesca), pasa revista a las diferencias y similitudes entre ellas, diferentes usos del tiempo y espacio, etc., aun reconociendo una clara deuda de Thebayda a Celestina.

1886. CANET VALLÉS, José Luis, «La Celestina en la 'contienda' intelectual y universitaria de principios del XVI», Celestinesca 32 (2008), 85-108.

En la primera parte, se expone - breve y claramente- las ideas enfrentadas del escolasticismo, nominalismo, lulismo, espiritualismo, escotismo y humanismo en el ambiente universitario cuando se escribió la primera Celestina. En la segunda parte, se analiza a la luz de 
estas contiendas la presencia de ellas en lo que sería el supuesto texto del primer autor (el primer auto).

1887. CANET VALLÉS; José Luis, «Humanismo cristiano, trasfondo de las primitivas comedias", en Relación entre los teatros español e italiano: siglos XV-XX, eds. I. Romera y J. L. Sirera (Valencia: Universidad - Col. Parnaseo, 2007), 15-28.

Ve en las comedias humanísticas Poliscena (1433) y Poliodorus (1445) los temas centrales del ambiente escolar-universitario que tendrán su continuación en Celestina, modificados para una mayor claridad en uno de los principios de la responsabilidad de las acciones del individuo (esp. en el tema libre albedrío introducido por Lorenzo Valla). Celestina presenta huellas de un nuevo modelo educativo atractivo a humanistas como Alonso de Proaza.

1888. CARMONA-RUIZ, Fernando, "La recepción de La Celestina en Alemania en el siglo XVI». Disertación doctoral de la Univ. Fribourg (Suiza), noviembre de 2007, 442 pp. Director: Hugo Bizzarri.

Un exhaustivo estudio de las dos traducciones $(1520,1534)$ de Celestina por el mismo traductor, Christoph Wirsung y de la imprenta y del grabador que hizo las ilustraciones que adornan las dos traducciones. Agrega interesantes conclusiones sobre el impacto de la obra en la cultura alemana. Ilumina la época de Lutero y el impacto que tenía sobre las modalidades de la segunda traducción. Propone que la versión se hizo a base de una edición de la traducción italiana de Milán, 1514, adquirida por Wirsung cuando estudiaba en Italia en 1519. La tesis está en red en la siguiente dirección: «http://ethesis.unifr.ch/theses»

1889. CARRILLO, Elena, "Memoria y parodia del amor cortés», en Actas del XI Congreso Internacional de la Asociación Hispánica de Literatura Medieval (León, 20-24 de septiembre de 2005) (eds. A. López Castro - L. Cuesta Torre), León, Universidad de León. Secretariado de Publicaciones, vol. I, 2007, 405-413.

El interés recae sobre la parodia del amor cortés y aduce los ejemplos de Calisto y Melibea. Sería más paródico el tema en una obra en el que el enamoramiento fuera visto como imposible. Celestina es menos paródica en este sentido, y es más clara la parodia en el caso de Don Quijote y Dulcinea.

1890. CASTELLS, Ricardo, "La melancolía y la unidad temática en La Celestina», en La Celestina 1499-1999, 41-51.

Un intento de vincular la figura de Rojas (en la "Carta» y en el "Prólogo») con el personaje y las palabras de Pleberio en el auto xxi. En 
cuanto a las fuentes de ideas y temas, ambos personajes son melancólicos (regidos por Saturno) y esto, según este autor, es lo que permite identificar la figura de Rojas con la filosofía de Pleber

1891. CASTRO, Eva, "La Biblia y el universo dramático medieval», en La Biblia en la Literatura Española. I. Edad Media. I/1 El imaginario y sus géneros. I/2 El texto: fuente y autoridad (dir. G. del Olmo, coord. M. I. Toro Pascua), Madrid, Trotta - Fundación San Millán de la Cogolla, I/1, 2008, pp. 191-220.

En las pp. 194-201 se exploran las referencias bíblicas en Celestina, proceso iniciado en la Celestina comentada. Se incluyen (198) en una lista por autos, que demuestra que el primer auto es de génesis diferente. La mayoría de las citas, tal vez sorprendentemente, salen de las bocas de los miembros de la clase baja.

1892. CHAVIANO, Daína, "Símbolos y arquetipos en la trinidad protagonista de La Celestina», Celestinesca 30 (2006), 9-25.

Asociaciones arquetípicas -estudiadas en los nombres de Calisto, Melibea, Celestina- que hacen de Celestina una obra simbólica colectiva y persistente más allá de las fronteras culturales. Intenta mostrar un nivel «no consciente» (no es lo mismo que inconsciente) en la decisión de nombrar a los personajes (a través de conexiones míticoalegóricas, etimológicas, cabalísticas y más). Los tres nombres referidos proyectan vínculos simbólicos que añaden duplicidad semántica a la obra, enriquecen los retratos y ofrecen pistas al destino fatídico de los tres.

1893. CHEVALIER, Jean-Claude, "Les paremies de La Celéstine: formes et principes de quelque traductions anciennes et modernes", Bulletin Hispanique 107.1 (juin 2005), 7-20.

Ejemplifica la fortuna de «quien torpemente subió a lo alto, mas ayna cae que subió» (auto I), "quien con modo torpe sube en alto, mas presto cae que sube» (auto v) y "proverbio es antiguo que de muy alto grandes caydas se dan» (auto XIII) en las traducciones de Hordognez (italiana, 1506), Lavardin (francesa, 1578), Mabbe (inglesa, 1631) y Heugas (francesa, 1963).

1894. COCOZZELLA, Peter, "Traces of Aristotle's Poetics in the Tragicomdia de Calisto y Melibea», Lemir. Revista electrónica sobre literatura española medieval y del renacimiento 10 (2006), 1-14.

El enfoque cae sobre el rol de Melibea y los efectos que tiene la anagnórisis (descubrimiento) que sufre con su desmayo en el auto $\mathrm{x}$, la peripeteia (cambio) que nos entrega una nueva Melibea en control de 
su destino (también desde al auto $\mathrm{x}$ ), y la hamartia o hubris que le caracteriza en el auto XVI. Melibea es más como Areúsa después de ocurrir las primeras dos citas y emerge como verdadera figura trágica aristotélica, algo como Adela en La casa de Bernarda Alba, con unas comparaciones interesantes observadas por el autor.

1895. CORRY, Jennifer M, "Celestina», en Perceptions of Magic in Medieval Spanish Literature. (Bethlehem, PA: Lehigh UP, 2005), pp. 178-190.

Detrás de la marginación de Celestina como mujer vieja y amenazante en la sociedad patriarcal de la Baja Edad Media, la autora percibe un proceso progresivo desde el paganismo (y la centralidad de la mujer Diosa) hasta el cristianismo. Así las actividades de Celestina, y en especial la hechicería, son vistas como indeseables en manos de mujeres que tienen, por lo tanto, que operar en secreto. El autor de la obra reconoce la influencia de las creencias mágicas en la época y deja abierta al lector su eficacia en la trama, aunque ofrece también cierto escepticismo.

1896. CRESPEAU, Jean-Baptiste, «El concepto filosófic de felicidad en La Celestina», Celestinesca 32 (2008), 109-130.

El concepto de felicidad presente en Celestina es la tripartita de la Ética de Aristóteles y se estudia a base de su léxico y las estructuras que dan forma y sentido a la obra. Y esto a pesar de la importancia en la obra del muy comentado pesimismo.

1897. DANGLER, Jean, "The Monstruous Body», cap. 5 de su Making Difference in Medieval and Early Modern Iberia. Notre Dame IN: U Notre Dame P, 2005, pp. 111-140.

Demuestra como el «monstruoso otro», aceptado por San Agustín, simbolizó el tercer elemento de una tríada en la Edad Media (descenso-ascenso-transcendencia) que, al ganar terreno el binarismo en la Baja Edad Media, se iba eliminando. Así se explica el imperioso rechazo de Celestina por parte de Rojas (caracterizada por su físico y sus métodos como una figura monstruosa), en un mundo en donde todas las formas del Otro se iban marginalizando, perdida la capacidad de incorporar las complejidades del cuerpo monstruoso en el nuevo sistema binario.

1898. DE ALBA KOCH, Beatriz, "La vieja beata en la Quijotita de Fernández Lizardi: una celestina a lo divino», Revista Canadiense de Estudios Hispánicos 32.1 (2007), 123-136.

Traza el paralelismo entre Doña María, la beata vieja de la obra (1818), y Celestina. Las dos son anti-patriarcales, atrayendo a las jóve- 
nes, bien a la prostitución (Celestina) o a la irracionalidad supersticiosa (Quijotita), cuya joven, Pomposa, acaba en la prostitución también. Comparten las dos obras muchas singularidades. Así que Lizardi daría nueva vida a la figura clásica de Celestina, igual que la dio a Lazarillo de Tormes en su Vida de Periquillo Sarmiento (1816).

1899. DEL BARRIO, Florencio, "Los términos de parentesco como formas de tratamiento en La Celestina", Anuario de Lingüística Hispánica (Valladolid) 19-20 (2003-2004), 201-226.

Una aproximación sociolingüística a los términos de parentesco estudiados por su variación estilística y su capacidad de mostrar relaciones de poder (asimetría) o solidaridad (simetría). Las variables son (a) clase social, (b) edad y (c) sexo. El análisis se limita a los autos I, IV, IX y XII. Se toma en cuenta tanto emisores como destinatarios, y también la intención comunicativa. Conclusiones: la clase social no es un factor determinante, y sí el destinatario, la persona a quien se dirige. En cuanto a los términos 'madre' y 'tía', solo Celestina es tratada así, tanto por los de abajo como por los de arriba.

1900. DEYERMOND, Alan, «Secretos de oriente, secretos de mujeres: los saberes prohibidos en la literatura medieval castellana», en El cuento oriental en Occidente, ed. M. J. Lacarra \& J. Paredes (Granada:.Fundación Árabe de Altos Estudios, 2006), 61-94.

De los diez apartados, sólo el último trata de Celestina (77-78), repasando en breve los saberes de la cosmética, de la restauración de vírgenes y de la medicina para dolencias de mujeres, artes que se relacionan estrechamente con la microsociedad que es el prostíbulo. Buena bibliografía.

1901. DEYERMOND, Alan, Poesía de cancionero del siglo XV, eds. Rafael Beltrán - J. L. Canet - Marta Haro, València, Universitat de València, 2007. 305 pp.

En las pp. 289-305 se reimprime su artículo del mismo título del año 1997 (en Cinco siglos de 'Celestina', aportaciones interpretativas).

1902. DEYERMOND Alan, "Rereading Stephen Gilman's The Art of 'La Celestina'", en Late Medieval Spanish Studies in Honour of Dorothy Sherman Severin, ed. J. T. Snow \& R. Wright (Liverpool: Liverpool UP, 2009), 121-132.

Deyermond rereads the 1956 volume by Gilman and reflects on its strengths and weaknesses as seen from the perspective of a half century of Celestina studies and is, in general, supportive of many of its 
finer analyses. New scholars would do well to read Gilman and this commentary in tandem.

1903. DI CAMILLO, Octavio, "Consideraciones sobre La Celestina y las instituciones dramatúrgicas del humanismo en lengua vulgar», en $\mathrm{La}$ Celestina 1499-1999, 53-74.

El autor ve Celestina, en esa visión caleidoscópica, como fruto de una tradición clásica teatral que, una vez publicada, se recibiría más bien como obra narrativa. El ensayo reconoce las muchas lagunas en la historia teatral de la península ibérica que frustran conclusiones más concluyentes sobre las prácticas humanísticas en los ambientes universitarios españoles, en contraste con las de las universidades italianas.

1904. DI CAMILLO, Octavio, "The Burgos comedia in the printed tradition of La Celestina: a Reassessment», en La Celestina 1499-1999, 235-323.

Postula que la fecha de 1499 para la edición de Burgos es más consistente que otras fechas posteriores propuestas por la crítica, rastreando información anterior sobre el incunable (Heber, Brunet, Salvá). En cuanto al primer folio ausente o la sustitución de la marca del impresor, relata como ha pasado de edición ordinaria a princeps. Sugiere que la marca del impresor es una cuidada copia manual para aumentar el valor del libro. Se cuestiona la propuesta de que Proaza corrigió una edición (Salamanca 1500), y asevera que había más ediciones circulando en España, de las cuales Burgos es la única sobreviviente. Burgos así representaría un estado avanzado de la Comedia, al menos un tercer estadio textual tras la tradición manuscrita y otra edición princeps (sin argumentos). En la hoja perdida de Burgos, había un argumento antes del retrato de Calisto y Melibea. La lectura contradictoria del espacio de la escena inicial (huerta o iglesia) sigue de la errónea interpretación de quien compuso los argumentos (¿Fadrique?). Además, es poco probable que hubiera páginas no numeradas que contuvieran los preliminares. Las estrofas finales de Proaza tampoco estuvieron en Burgos. Las marcas de agua de papel muestran que no hubo tampoco folios adicionales al final de Burgos 1499

1905. DUMANOIR, Virginie, «Le pouvoir et la violence dans La Célestine», Celestinesca 32 (2008), 131-150.

El didactismo de Celestina se ve a través de una definición jurídica del poder bien aplicada al autor y su público. La relación entre lectores y autor se aclara al ver aumentado el poder en distintos personajes, manipulados por Celestina, que terminará en actos violentos. El proceso de captación del mensaje del texto es resultado de esta dialéctica entre poder y violencia. 
1906. DUQUE, Félix, «El sujeto del deseo en La Celestina», en Welterfahrung-Selbsterfahrung, eds. W. Matzat \& B. Teuber (Beiheften zur Iberoromania, 16, Tubingen: Max Niemeyer, 2000), 7-21.

El «sujeto» aquí no es el personaje, sino la persona que en determinados momentos (y sólo en esos momentos) llega a ser «señor de su voluntad y libre en su acción» (20). Ocurre con Melibea en el auto XX $y$ con Celestina en el auto XII. Es un estudio sugerente, lleno de nuevas direcciones para futuros celestinistas.

1907. ECKART, Gabriele, "Celestina, a Spanish Novel on the East German Stage before and after German Reunification", Celestinesca 30 (2006), 27-41.

Considera dos adaptaciones diferentes de Celestina por parte de dos autores de la Alemania Occidental. La primera, de Karl Mickel (1976) convierte a la Inquisición en un elemento activo e identificable con la policía del estado comunista. Las muertes de Calisto y Melibea responden a un plan de la Inquisición, con un origen oscuro de ambos que anuncia la sociedad post-feudal (post-comunista). La segunda adaptación, de Manfred Wekwerth (2002), al contrario, cuestiona los cambios traídos por el capitalismo tras la desaparición de la RDA. La reunificación de las dos Alemanias sería la de la de España de los Reyes Católicos, con críticas de la recién institucionalizada Iglesia alemana, la corrupción moral del capitalismo (simbolizada por Celestina y las relaciones entre criados y amos), o las políticas contra los extranjeros de la nueva Alemania reunificada (serían los judíos de la España de los Reyes Católicos).

1908. FERNÁNDEZ, Enrique, "La antítesis de la Anunciación y el reconocimiento de la redención en Celestina», La Corónica 35.1 (Fall, 2006), 137-150.

Pretende mostrar que el texto de Celestina - aun siendo pesimistaestá construido para admitir la contemplación de la Redención Universal cristiana. Las alusiones están implícitas en las menciones de la Caída y en otros pasajes, aquí detallados y analizados para defender la noción de que el pesimismo de la obra nunca es anticristiana.

1909. FERNÁNDEZ, Enrique, "La Celestina en la comedia de magia: Los polvos de la madre Celestina (1841) de Hartzenbusch", Theatralia 10 (2998), 89-104.

La obra de Hartzenbusch, adaptada de una obra francesa, sustituye la hechicera de ésta con su Celestina, ahora figura cómica heredada de las "comedias de magia» populares en la época pero con algunas características de la original. Buena recreación del teatro de la época. 
Se vio en una reposición de 1855, del mismo Hartzenbusch, y aludido en el Amadeo I de Galdós (1971), una entrega de los Episodios nacionales.

1910. FERNÁNDEZ ÁLVAREZ, Manuel, Sombras y luces en la España imperial. Espasa Forum, Madrid: Espasa, 2004.

"El mundo de La Celestina» (169-181) explora, contra la realidad de la época, la presentación literaria de los estamentos sociales en la obra. Su análisis detalla cada uno de los personajes que forman parte o del patriarcado urbano o del hampa. Por esta visión particular, ve en el autor de Celestina un hijo de su tiempo, "personaje del mas puro Renacimiento» (180).

1911. FERNÁNDEZ SAN EMETERIO, Gerardo, «Quejas por un cordón: burlas y veras con Camões y Fernando de Rojas», Rilce (Revista del Instituto de Literatura y Cultura Españolas, Pamplona) 20 (2004), 51-62.

Ve en el soneto de Camões ("Lindo e sotil trançado que ficaste») pu tos de contacto con el trato fetichista de Calisto por el cordón (Celestina, auto VI), aunque en el caso de Calisto esta adoración acopla bien con su carácter literario, mientras en Camões sale poco favorecido.

1912. FERNÁNDEZ VALLADARES, Mercedes, La imprenta en Burgos (1501-1600). 2 vols. Madrid: Arco/Libros, 2005. Vol. I: 352-368.

Una consideración exhaustiva de todas las importantes revisiones de los problemas materiales, editoriales y bibliográficos desde 1836 hasta entrado el siglo xxI del único ejemplar (mutilado por principio y final) de la Comedia de Burgos publicada por Fadrique de Basilea, en la Hispanic Society of America de Nueva York. Ofrece las dos posibles formulas de colación (353, col. a) como punto de partida aunque cree que la mas probable es la de 92 hojas en $4^{\circ}$ ( 23 pliegos). Por la todavía oscuridad que rodea todos estos problemas, opta por un arco de 14991501 en cuanto la datación.

1913. FOLGER, Robert, «Passion and Persuasion: Philocaption in $\mathrm{La} \mathrm{Ce}$ lestina». La Corónica 34.1 (2005-2006): 7-29.

Su esencia es ésta: Melibea rechaza con contundencia a Calisto en la primera escena (no está coqueteando). El rico análisis del diálogo de Melibea y Celestina (auto IV) explica cómo Celestina saca la imagen negativa que tiene Melibea de Calisto, agrega nueva información positiva, y hace que esa imagen negativa termine convertida en positiva -el inicio de la philocaptio. Sin ser necesaria la magia, tampoco está mal verla como un auxilio. El análisis se aproxima al problema del cambio repentino en la doncella recurriendo a conceptos familiares del siglo xv. Es buena la bibliografía. 
1914. GAGLIARDI, Donatella, "La Celestina en el Índice: Argumentos de una censura», Celestinesca 31 (2007), 59-84.

Un progresivo repaso de la opinión de los autores moralistas desde las primeras décadas del siglo XVI hasta finales del siglo XVIII sobre al valor de Celestina, desde las recomendaciones de su condena para los lectores comunes hasta la apología de otros a base de su contenido moral, terminando en la definitiva prohibición de la obra en 1793 . Un repertorio bastante exhaustivo que ilumina la historia de su recepción.

1915. GALVÁN, Luis, "Imágenes y anagnórisis en La Celestina», Nueva Revista de Filología Hispánica 53.2 (2005), 457-479.

Un análisis de las imágenes relacionadas con los dos amantes, comenzando con lo celestial y, de allí, descendiendo los niveles de la Gran Cadena del Ser al ser humano, los animales, las cosas, y lo diabólico. Termina con el acto XIX ("el que quiere comer el ave, quita primero las plumas»), cuando los amantes reconocen y aceptan —es la anagnórisis - la degradación de lo animalesco (revelado aquí, como en toda la obra, mediante las imágenes).

1916. GARACHANA CAMARERO, Mar, "La extensión del artículo indefinido durante la Baja Edad Media", en Actas del VI Congreso Internacional de Historia de la Lengua Española (Madrid, 29 de septiembre - 3 de octubre de 2003) (eds. J. J. de Bustos Tovar - J. L. Girón Alconchel), Madrid, Arco/Libros, 184 S. L., vol. 1, 2006, 689-697, Col. Filología. Actas y Homenajes.

Estudia el proceso de la gramaticalización del artículo indefinido del siglo XIII al XV (donde figura Celestina) y los datos demuestran una evolución hacia la indefinitud por forjarse en nuevos lugares sintácticos gracias al aumento de los elementos léxicos que lo permiten. El siglo XV no es, por lo tanto, muy distinto del siglo XXI. Hay varios ejemplos sacados de Celestina.

1917. GARCÍA VALDECASAS, José Guillermo, "Celestina y celestinesca», en Mitos literarios españoles (Madrid: Real Academia de España en Roma, 2004), 33-42.

Exceptuando algunas ediciones facsimilares, deplora la ausencia en el mercado del formato de la Comedia de Calisto y Melibea - de una superioridad "asombrosa» a la Tragicomedia - en el mercado editorial. En este formato es puro teatro, al espejo del teatro italiano, y hace innecesaria la tonta pregunta sobre el porque no se casan los protagonistas (Calisto está muerto en el segundo de los tres días de sus acciones, el primero de los cuales abarca los autos I-ViI!). 
1918. GARRIDO ARDILA, J. A., Charlotte Temple: Estudio de tradiciones, géneros y fuentes. Cáceres: Universidad de Extremadura, 2002. 253 pp.

Es en las pp. 217-228 que el autor, después de un minucioso estudio de la novela de Susana Rowson (1791), compara y contrasta Celestina y Charlotte Temple, sus propósitos iniciales, sus personajes principales (Celestina, Pleberio, Melibea, Calisto y Sempronio), y sus situaciones, y declara que no sólo fueron conocidas las dos traducciones al inglés de la obra (James Mabbe, John Stevens) en el siglo XVIII, sino que era, efectivamente, la fuente principal de la obra de Rowson.

a. Celestinesca 30 (2006), 127-129, T. L. Darby

1919. GASIOR, Bonnie, "An Interview with Keith Fowler and Glenn Odom of UCI's Production of La Celestina: 'If Only I Had Used that Stupid Girdle'», Comedia Performance 5.1 (2008), 169-185.

Esta entrevista con el director y el dramaturgo de la producción en el Claire Trevor Theater de la Universidad de California-Irvine (UCI) el 9-11 y $16-18$ de noviembre de 2006 recorre ideas puestas en práctica y evaluaciones del impacto en el público. Se basó (con recortes; llegó a dos horas y media) en la traducción de James Mabbe (1631).

1920. GATLAND, Emma, "Language and Authority in Celestina: Institutions, Incongruence and Shifting Symbolic Power», Celestinesca 31 (2007), 85-102.

Empleando la teoría del sociólogo francés, Pierre Bourdieu, que reconoce la legitimidad del poderío según las construcciones sociales en que funciona, la autora investiga los cambios del ejercicio del poder en el discurso de Melibea y Celestina, con el fin de probar que cuándo se entremezclan dos mundos ficticios (el amor cortés y la prostitución) la autoridad lingüística se ve afectada irrevocablemente y que, por lo tanto, el lenguaje en Celestina se desestabiliza en la misma proporción que en la que otorga poder.

1921. GIRÓN-NEGRÓN, Luis M., Alfonso de la Torre's 'Visión deleytable'. Philosophical Rationalism and the Religious Imagination in 15th Century Spain. Leiden/Boston/Colonia: Brill, 2001.

Rojas poseyó una copia de Visión deleytable. En las págs. 251-270 («Fernando de Rojas as a Reader of Visión»), G-N explora la posible influe cia de esta obra en el pesimismo radical de Rojas. Compara semejanzas en la utilización de la psicología de las pasiones en las sententiae de Aristóteles en las dos obras y también la pérdida del solaz en el orden de una Providencia benévola en el mundo de Celestina. 
1922. GÓMEZ-MONTERO, Javier, "Celestina, Lozana, Lázaro, Urdemalas y la subjetividad. A propósito del lenguaje y los géneros en la 'escritura realista' del Renacimiento", en El personaje literario y su lengua en el siglo XVI, eds. C. Baranda Leturio \& A. Vian Herrero (Madrid: Universidad Complutense, 2006), 285-340.

¿Ha contribuido este estudio del género, lenguaje y personajes de unas pocas obras áureas a definir huellas de incipiente subjetividad en la ficción renacentista sobre la base de la epistemología poética subyacente a la escritura realista del siglo XVI?» (340). Podemos contestar afirmativamente a la pregunta del autor. Páginas esenciales para Celestina son 300-304 y 320-324, entre otras muchas observaciones menos extensas.

1923. GONZÁLEZ FERNÁNDEZ, Luis, «Algunas consideraciones sobre la criada Lucrecia», Celestinesca 32 (2008), 151-164.

Que se sepa, es ésta la primera vez que se sugiere que el maleficio descrito por A. Deyermond (1977), que afecta al comportamiento de Melibea, Calisto y Celestina, finalmente afecte a Lucrecia cuando abraza a Calisto en el auto XIX.

1924. HERMENEGILDO, Alfredo, «Fulgores de la representación: El texto celestinesco de Ruano de la Haza», Theatralia 10 (2008), 133-150.

Después de un corto repaso del debate sobre el género de Celestina (novela, teatro, etc.), analiza la dramaturgia de Ruano de la Haza en su adaptación (estreno: Almería 2004), en la que sólo quedan cinco personajes de la obra original (la alcahueta, los amantes, Sempronio y Sosia). Le interesa cómo está presente el hipertexto en la nueva obra (voces en off, referencias a personajes no presentes, absorción de los actores ausentes en los actantes presentes) y cómo utiliza las didascalias del original que modifica y minimiza en su versión para efectuar una obra que demuestre toda la fuerza escénica que poseía el texto original.

1925. HERRERA JIMÉNEZ, F. J., "(Des)vestir el cuerpo en la materia celestinesca», en II Jornadas internacionales sobre moda y sociedad, ed. M. I. Montoya (Granada: Universidad, 2001), 177-185.

Unas notas hacia un trabajo más elaborado de lo corporal en el sistema semiótico de lo celestinesco en las que la mujer tiene un «interés funcional como cuerpo desnudo" (178) en Celestina (no tanto en Lozana). Como el hombre ofrece más sentido en su variante vestido, comienza la exploración de su atuendo (calzas, jubones, etcétera).

1926. HERRERA RUIZ DE LOIZAGA, F.J., «El monólogo en la comedia celestinesca: aspectos lingüísticos y textuales», en El personaje literario 
y su lengua en el siglo XVI, eds. C. Baranda Leturio \& A. Vian Herrero (Madrid: Universidad Complutense, 2006), 79-105.

Un estudio de «algunos de los muchos puntos del monólogo celestinesco que son dignos de atención» (105). Las obras estudiadas son: Celestina, Segunda Celestina (1534), Lisandro y Roselia (1542), Selvagia (1554) y Seraphina (1521), y en un apartado especial, la Tragedia Policiana (1547), el planto final. Los tipos de monólogos incluyen los de contenido retórico de estilo alto (llantos y disertaciones sobre el amor), la expresión de pensamientos personales o monólogos interiores, indicadores de situaciones, el cubrir el espacio temporal de desplazamientos, apartes monologados y otros dirigidos, al menos en parte, a otras personas, abstracciones, o al hablante mismo.

1927. HERRERO RUIZ DE LOIZAGA, F. J., "Procedimientos para la expresión del humor en la comedia celestinesca», Cuadernos del CEMYR 12 (2004), 69-95.

Con ejemplos y un análisis descriptivo, profundiza en los diferentes tipos de humor en las comedias posteriores a Celestina, pero dentro de la celestinesca. Básicamente, es un humor de situación, con referencias eróticas, algunas escatológicas, ironías y chistes de doble sentido.

1928. HEUSCH, Carlos, L'invention de Rojas: La Celéstine. Paris: Presses Universitaires, 2008. Rústica, 165pp.

En resumen, en el lustro 1499-1504, nace un escritor: Fernando de Rojas. Sigue el proceso de adaptación, creación y re-escritura, paso por paso, desde la CCM hasta la TCM (en la re-escritura y creación del Tratado de Centurio), mediante las supresiones, amplificaciones, cambios estructurales (esp. en el Tratado) y en la introducción, sobre todo en los monólogos, de la superioridad de la "palabra» a la invención y maestría del diálogo. Parece desconocer los estudios que ponen en cuestión el rol de Rojas en la obra (ver la bibliografía).

1929. IGLESIAS, Yolanda, Una nueva mirada a la parodia de la novela sentimental en "la Celestina», Medievalia Hispanica, 12, Madrid/Frankfurt: Hispanoamericana-Vervuert, 2009. Rústica, 127pp.

Después de examinar en los capítulos 1-4, siguiendo los críticos anteriores, la parodia en Celestina y del amor cortés en la novela sentimental y en Celestina, dedica el capítulo 5 al tema del título de esta monografía - y de nuevo, expresando su acuerdos y desacuerdos con la crítica previa - la parodia de la novela sentimental en Celestina, que es considerada operante «desde el inicio de la obra hasta el final» (77). 
1930. INFANTES, Víctor, «Fernando de Rojas: el lector desvelado (en su caligrafía). De nuevo sobre el 'Inventario de sus libros'», Celestinesca 31 (2007), 103-118.

Después de un anterior estudio sobre este Inventario, el autor vuelve a centrar su atención en un libro de leyes (Las cortes de Toledo [Burgos 1526]) que sí estaba en posesión de Rojas y que ha sobrevivido. Lo más interesante es que es un libro con marginalia escrita a mano que bien puede ser la caligrafía del licenciado jurista y posible autor de Celestina.

1931. KISH, Kathleen V., "Celestina sale a las tablas en México», en Actas del XV Congreso de la Asociación Internacional de Hispanistas "Las dos orillas» (Monterrey, México. Del 19 al 24 de julio de 2004) (eds. B. Mariscal - A. González), México, D. F., Fondo de Cultura Económica - Asociación Internacional de Hispanistas - Tecnológico de Monterrey - El Colegio de México, 2007. vol. I: 379-388.

Repasa la historia de las representaciones teatrales de la obra en México, comenzando con las de A. Custodio (1953-1968) y los problemas con la censura, hasta las más recientes de Sabido y Villaseñor (cine), Buch, French/Garcini y Ríos (danza, 2000). Hay comentarios sobre la versión final de La segunda Celestina (posible agregado de Sor Juana Inés de la Cruz), de un poema de León Felipe, de las ilustraciones de M. Prieto (1947) y del ruso Vlady para las obras de Custodio.

1932. LA CELESTINA 1499-1999. Selected Papers from the International Congress in Commemoration of the Quincentennial Anniversary of La Celestina (New York, November 17-19, 1999, eds. O. Di Camillo \& J. O'Neill. New York: Hispanic Seminary of Medieval Studies, 2005. Tela, 359 págs. ISBN 1-56954-096-9.

Contiene 14 artículos, todos reseñados en este suplemento bajo: La Celestina 1499-1999.

a. Bulletin of Hispanic Studies 83.4 (2006), 438-439, E. Vaccaro

1933. La dramaturgia de 'La Celestina', ed. J. M. Ruano de la Haza \& J. G. Maestro. Vigo: Ed. Academia del Hispanismo, 2008. Rústica, 217 pp. Ilustrado.

Es un número de la revista Theatralia (vol. 10) con una presentación, ocho estudios y el texto completo de la adaptación de Celestina por J. M. Ruano de la Haza, todos reseñados en este suplemento.

1934. LACARRA LANZ, Eukene, "Las pasiones de Areúsa y Melibea», en La Celestina 1499-199, 75-109. 
En un exhaustivo y bien documentado análisis del «mal de madre», la autora compara y contrasta los dos casos de Areúsa (auto VII) y Melibea (autos IV y $\mathrm{x}$ ) a la luz de las características, los síntomas y los remedios (el coito, en particular) recomendados médicamente en tiempos de la creación de Celestina. La enfermedad de Areúsa se debe, se cree, a su excesiva lascivia, pero la de Melibea corresponde a una grave pasión anímica que le ha alterado.

1935. LACARRA LANZ, Eukene, “'¡Ya todos amamos?’. La degradación del amor hereos en Celestina", en Asimetrías genéricas: 'Ojos ay que lagañas enamoran'. Literatura y género, ed. E. Lacarra Lanz (Bilbao: Univ. Del País Vasco, 2007), 33-75.

En este extenso estudio, se identifican las fuentes médicas que son la base del concepto del amor hereos (desde Aristóteles y Galeno hasta las autoridades del siglo xv) y, hecho esto, se analizan las tres etapas de la obra (el auto primero, la Comedia, las interpolaciones en le Tragicomedia) donde encuentra la autora la progresiva degradación de una enfermedad supuestamente asociada con la nobleza en algo semejante a la lujuria pagada y comercial de los criados. Con una nutrida bibliografía al final.

1936. LAGE COTOS, María Elisa, «Segundo el Taciturno y Celestina Comentada (Madrid BN MS. 17631)", en Actas del XI Congreso Internacional de la AHLM (sept., 2005), ed. A. López Castro y L. Cuesta Torre, León: Universidad, 2007, vol. II: 243-54.

Lage presenta las tres ocasiones cuando el comentarista cita a Segundo (autos 1,3 y 4) y comenta los temas aducidos además de cómo llegó a conocerlos el comentarista. Especialmente interesante es el tercer caso, que conjetura viene de Antonio de Guevara, una fuente no mencionada por los editores. Los tres temas son: la mujer, la pobreza y la belleza.

1937. LARA ALBEROLA, Eva, "Testamento de Celestina: una burla de la hechicería", Celestinesca 30 (2006), 43-88.

Se trata de un pliego suelto de 1597 del ciego Cristóbal Bravo, que toma la forma de una parodia del testamento legal. En esta parodia, Celestina deja su laboratorio a las mujeres que serán sus herederas, con consejos sobre la magia y el ars amandi. Representa un compendio de la sabiduría popular sobre las tradiciones orales de la magia, pasado por el filtro cómico

1938. LAWRANCE, Jeremy, "Representations of violence in 15th-century Spanish literature», en Late Medieval Spanish Studies in Honour of Doro- 
thy Sherman Severin, ed. J. T. Snow \& R. Wright (Liverpool: Liverpool UP, 2009), 95-103.

Termina esta exposición de la violencia con un excursus en Celestina. Rojas no sólo lo incorpora porque es un factor verosímil de la vida peligrosa que pinta, sino también para demostrar el sentido violento de la incoherencia en la estética gótica, en particular en la TCM (ver el Prólogo).

1939. LEAÑOS, Jaime, "La Celestina: ¿Philocaptio o apetito carnal?», Fifteenth-Century Studies 32 (2006), 68-82.

Tras adoptar una postura intermedia entre las dos tendencias críticas sobre la funcionalidad de la magia en Celestina, en primer lugar muestra el arraigo de esta actividad en la sociedad española del siglo XV, usándose sobre todo de referente el Maellus maleficarum (ca. 1486) de J. Sprenger y H. Kraemer. A continuación, profundiza en los antecedentes clásicos de la magia, recurriendo al Memorabilia de Jenofonte, la Andrómaca e Hipólito de Eurípides, la Aethiopica de Heliodoro - philocaptatio-y otros ejemplos de Aristóteles y Plinio el Viejo -farmacia-. La función de la magia sería la de una observación cultural que aportaría vitalidad, colorido y fluidez expresiva a la philocaptatio de Melibea, verdadero eje sobre el que se articularía la trama de la obra [RA].

1940. LEAÑOS, Jaime, "God, the Devil, and Cupid: a Tripartite Formula for a Sinful Death", eHumanista 9 (2007), 143-160.

Teniendo en mente el presupuesto de que la intención de Fernando de Rojas habría sido escribir una obra de orientación sexual, se examina lo propuesto por este autor como un speculum del mal personific do en dos pecados mortales: la avaricia y la lujuria. Estos pecados se analizan desde la base del De Malo de Santo Tomás, obra escolástica a la que Rojas habría tenido acceso en Salamanca, y son vistos como el motor de los cinco personajes principales: Calisto y Melibea - lujuria-, Celestina, Pármeno y Sempronio —avaricia. Desde las enseñanzas éticas tomistas, Rojas intentaría dar una lección moral a sus receptores, mediante la presentación de un espejo cuya función sería instigar a sus contemporáneos a actuar de forma diferente a la de sus cinco malogrados protagonistas [RA].

1941. LEMA-HINCAPIÉ, Andrés, «Borges y el medioevo literario de España», Bulletin Hispanique 109.1 (2007), 205-233.

La sección IV (de viI) se dedica a Celestina (210-212). Atribuye a Borges su gusto por la enumeración a la técnica tantas veces usadas en Celestina (cita como ejemplo la descripción que hace Pármeno del laboratorio de la alcahueta). 
1942. LLORET, Albert, «El error retórico de la alcahueta. Performatividad y nueva retórica en la Celestina», Celestinesca 31 (2007), 119-132.

Se examinan y analizan dos trozos de la retórica celestinesca, el diálogo con Pármeno (auto I) y su defensa ante Pármeno y Sempronio que le lleva al asesinato a manos de ellos (auto XII). Se ponen de relieve, del primero, varias de sus estratagemas retóricas no codificadas en los tratados clásicos y, en el segundo, el error retórico que le lleva a su muerte. Se echa mano en este fino análisis de los preceptos de Chaim Perelman en su Tratado de la argumentación.

1943. LÓPEZ, Fernando J., Melibea. Monólogo teatral, Centro Cultural Moncloa (Madrid), 18 y 25 febrero de 2008.

El monólogo de una hora fue protagonizada por Silvia López ORTEGA, con coreografía de la misma. Dirección: Fernando J. López, y música de Carmen Alonso, interpretada por María Dolores Gutiérrez. Esta Melibea, basada en la de la Tragicomedia después de su suicidio, se ve multiplicada en muchas mujeres conocidas hasta el día de hoy. Viaja en un tranvía que atraviesa el libro del tiempo, testigo ella de las cambiantes realidades sociales, mientras nos ofrece una versión nueva de sus relaciones con Celestina, con su madre, Alisa, y muchas más. Hay notas en el programa que recuerdan a Julieta, Beatrice, Sherezade y otras mujeres. Se destaca la noción de la histórica mutilación de la dignidad de todas las mujeres.

1944. LÓPEZ GRIGERA, Luisa, "La Celestina: Causas de las acciones de los personajes", en La Celestina 1499-1999, 111-124.

Los autores de Celestina demuestran tener un hondo conocimiento de lo que Aristóteles escribía sobre las acciones de los seres humanos (Retórica, Organum, Ética Nicómaca). En Celestina, siempre se acentúa lo no racional de las decisiones, el egoísmo y el interés personal en plena función de lo pasional.

1945. LÓPEZ IZQUIERDO, Marta, "Personaje y lengua en La Celestina: Nuevas perspectivas de estudio», Celestinesca 32 (2008), 165-190.

Lo importante es la nueva valoración del diálogo en Celestina. Aproximación que realiza desde (1) la oralidad, (2) los dialectos sociales y (3) los registros de los apartes. Su análisis se estructura a base de ejemplos y comentarios útiles, y sugiere que lejos de la falta del decorum clásico, los autores pretenden escribir la oralidad natural, aun teniendo que negociar entre asuntos lingüísticos y retóricos.

1946. LÓPEZ-RÍOS, Santiago, «La oración a Santa Apolonia de la Celestina a la luz del folklore médico-religioso», Theatralia 10 (2008), 59-76. 
Un estudio amplio que recoge las tradiciones de Santa Apolonia desde su martirio y la devoción hacia ella en textos y en la tradición oral (de distintos países), como preparativos para un análisis de su funcionamiento en el auto IV de Celestina. Incorpora el autor en sus comentarios un inteligente comentario interpretativo de cómo funciona esta oración en la comunicación implícita entre doncella y alcahueta en el registro erótico.

1947. LÓPEZ-VIDRIERO, María Luisa, «La 'Celestina de Palacio': un origen no tan cierto", en La Celestina 1499-1999, 125-151.

Una minuciosa secuencia de informaciones sobre la biblioteca de Diego Sarmiento de Acuña, primer conde de Gondomar, y la colección que contenía el libro facticio con el único manuscrito parcial de Celestina. Es una impecable y fidedigna reconstrucción de la historia de ese manuscrito, profusamente ilustrada.

1948. LOZANO-RENIEBLAS, Isabel, "La Celestina en el contexto de los pactos demoníacos», en La Celestina 1499-1999, 153-164.

Convencida de la eficacia de la magia de Celestina en el cambio de voluntad de Melibea, la autora pone de relieve otros relatos anteriores con pactos demoníacos, fortaleciéndolos con la fama de Salamanca como centro de la nigromancia, para dar solidez a la idea de que es la magia la que hace que Melibea renuncie a su castidad.

1949. MAESTRO, Jesús G., El mito de la interpretación literaria: Rojas, Cervantes y Calderón: la ética de la literatura y sus dogmas contemporáneosMadrid: Iberoamericana, 2004.

Libro interesante del cual poco se dedica a Celestina ("La magia y el poder sobrenatural en la literatura", pp. 64-70).

1950. MAESTRO, Jesús G., «La dramaturgia de La Celestina, o el fenómeno de la transducción en la literatura teatral», Theatralia 10 (2008), 11-24.

En su presentación, Maestro comenta brevemente los estudios incluidos en este número de la revista, Theatralia, y expone sus ideas sobre la relación entre literatura y teatro. En manos de los intermediarios (actores, directores) - $\mathrm{O}$ sea, transductores- las representaciones multiplican los signos y significados del texto literario

1951. MAESTRO, Jesús G., "Idea de la libertad en La Celestina desde el materialismo filosófic como teoría de la literatura», Celestinesca 32 (2008), 191-208.

Un minucioso examen de la noción de la libertad en Celestina (pp. 200-205), cuando la libertad sólo se ve como una perpetua lucha por el 
poder (o por los poderes) para conseguir el control sobre los demás. Es decir, la libertad es algo que depende del resultado final del proceso, en términos del materialismo.

1952. MARCOS CELESTINO, Mónica, "Tradición clásica y ecos literarios de Grecia y Roma en La Celestina», Estudios Humanísticos-Filología 28 (2006), 73-118.

En forma diluida pero recuperable, hay en Celestina la presencia del mundo greco-romano. Se sugiere que para el autor, estos 'conocimientos' vienen en una forma indirecta y superficial, posiblemente pasados por Petrarca y traducciones al castellano de otros autores, tanto griegos como latinos, todos ellos estudiados aquí con una amplia bibliografía citada en notas.

1953. MÁRQUEZ VILLANUEVA, Francisco, «2008: Suma y sigue de La Celestina", en Late Medieval Spanish Studies in Honour of Dorothy Sherman Severin, ed. J. T. Snow \& R. Wright (Liverpool: Liverpool UP, 2009), 182-188.

Cuando aparece Celestina en la España multicultural y de crisis, nació de golpe y con una madurez inigualada. Sólo La Dorotea de Lope puede con su peso. Tampoco fuera de España tuvo mucho impacto. Conserva, pero bajo otro signo, el sello hispano-semítico, aunque la crítica moderna se polariza sin hacer grandes avances. Rojas «se arropa de ambigüedades» (184), haciendo menos fácil para los modernos ver con claridad su gran revolución literaria.

1954. MARTÍNEZ TORREJÓN, José Miguel, «'Apártate allá, Lucrecia’. La violación de Melibea", en La Celestina 1499-1999, 165-187.

Explora temas del rapto de Lucrecia por Tarquino con ecos en Celestina, en cuanto la violencia usada durante la violación de la deseada. Examina los distintos gradus rapti en el contexto ovidiano para explicar la expectativa del uso de la fuerza en la seducción de la dama. El texto nos da un compendio de las obras literarias que siguen las fórmulas ovidianas en las escenas de seducción para justificar su lectura particular de Celestina.

1955. MENCÉ-CASTER, Corinne, «Temporalité et éthique dans La Célestine», Celestinesca 32 (2008), 209-230.

La falta de ética y valores cristianos de los personajes de Celestina reciben un trato especial. Sus acciones ante el tiempo son factores esenciales en la determinación de ciertas responsabilidades morales y cuestionan importantemente la libertad humana a la que pretenden aspirar. 
1956. MIAJA, María Teresa, «'Agora que voy sola...' en boca de Celestina», Olivar 9, núm. 11 (2008), 27-37.

Pormenorizado análisis del monólogo de Celestina (auto Iv) que capta no sólo la esencia del personaje, pero ofrece claves de interpretación para los otros personajes que ella incluye en su autocuestionamiento íntimo. Hay también énfasis en su uso de lenguaje.

1957. MIER, Laura, «La conciencia de Melibea», Celestinesca 32 (2008), 231-244.

Melibea quiere dos cosas: el amor y el secreto, es decir, que no se sepa de ese amor en público. Este estudio escudriña cómo esta postura se puede ver en cada una de las actuaciones en que aparece la amante de Calisto desde el comienzo hasta su suicidio, analizadas con minuciosidad. Esta Melibea conocedora de sí misma no requiere la magia de Celestina en la determinación de sus acciones.

1958. MONTES GARCÉS, Elizabeth, "Cuerpo, deseo y lenguaje en la Celestina y Sirena Selena vestida de pena", Revista Canadiense de Estudios Hispánicos 32.1 (2007), 189-202.

Muestra interesantes similitudes entre Celestina y Martha Divine, el travesti regente de un burdel en esta novela de Mayra Santos (2000). El travesti ayuda a negros puertorriqueños a transformarse en drag queens que se prostituyen con turistas: comparte en su actuación muchas características con Celestina. Sobrepasan ambas las barreras de género y clase (en el caso de Martha, también de raza), detentan el papel de madres, transforman lo corporal y se valen de la lengua para la manipulación de sus víctimas. Se convierten en mediadoras en busca de mercancía lucrativa. Según la autora, ambos refuerzan el valor patriarcal de la virginidad (Celestina) o trabajan para una sociedad de consumo masculina que perpetúa el status quo (Martha).

1959. MONTI, Silvia, «Il personaggio di Celestina in due drammi contemporani», Quaderni di Lingue e Letterature 27 (2002), 119-136.

Se trata de un análisis de las Celestinas de dos obras, la primera de J. Martín Recuerda, Las conversaciones (1974-1978) y la segunda de Alfonso Sastre, La taberna fantástica de la gitana Celestina (1985).

1960. MORAL DE CALATRAVA, Paloma, «Magic or Science? What 'Old Women Lapidaries' Knew in the Age of Celestina», La Corónica 36.1 (2007-2008), 203-235.

Cubre mucho espacio en cuanto a los profesionales y no profesionales de la medicina en los siglos XV y XVI (las mujeres pertencientes al 
segundo grupo), y lo que los médicos profesionales aprendían de la experiencia de ellas. En cuanto a Celestina, la discusión se limita al 'dolor de la madre' y los remedios propuestos por Celestina y cómo eran unos de los más recomendados en los tratados médicos clásicos y contemporáneos, incluso en el Sumario de la medicina del doctor Villalobos.

1961. MORROS MESTRE, Bienvenido, “'Mira a Bernardo' y los autores de La Celestina», Medioevo Romanzo 26.2 (2002), 296-310.

El autor percibe entre el 'antiguo autor' y Rojas una tercera mano que habría corregido un "mira a Vergilio» en "mira al Bernardo». La lista del antiguo autor se basaría sin duda en Piccolomini y su Historia de duobus amantibus y la enmienda en el manuscrito de Palacio vendrá de uno atento al pasaje semejante en el Arcipreste de Talavera, habiendo visto la similitud entre el caso del engaño de Virgilio y el de Mosén Bernat Cabrera.

1962. MOYA, Pablo César, «La muerte de Alda y el suicidio de Melibea. La ideología del amor como desenlace narrativo", en Amor y erotismo en la literatura (Congreso Internacional. Universidad de Salamanca, 1998), Salamanca: Caja Duero, 1999, 205-212.

Distintas son estas muertas: Alda se muere por defender su honor y castidad, negando aceptar a otro. El caso de Melibea está lejos en forma y sentido, el de una mujer que no se arrepiente de su pasión y aludiendo a ella al invocar a Dios. Son dos maneras distintas de la «muerte por amor» como desenlaces en la literatura medieval. Otros ejemplos presentados de las mujeres que se sacrifican por amor, faltando sus amantes, pero no como Melibea, proceden del Zifar, el Libro de los Estados y la Crónica sarracina.

1963. NUÑEZ RIVERA, Valentín, «Por arte se ha de regir el amor: El proceso de recuesta según Ximénez Urrea». Celestinesca 30 (2006): 89-109.

Visión de la Penitencia de amor (PA) de Ximénez de Urrea como un arte de amores, cuya condición de producto híbrido anuncia el final de la etapa del Amor Cortés. Se contrastan la estructura y otros elementos de PA con los de obras como Cárcel de amor, la Historia de duobus amantibus y Celestina. En relación con ésta, ambas empiezan in media res, el amor es facilitado por terceros (aunque los criados de PA están libres de amor y son fieles al amo), Davino coincide en pasión lasciva con Calisto, y el cambio espectacular de Finoya y su 'fingido enojo' recuerdan a los de Melibea. No obstante, los desenlaces son diferentes. Se cree que la inserción de pullas humorísticas en $P A$ señala una mirada irónica al convencionalismo del género sentimental. 
1964. PALAFOX, Eloísa, «Celestina: Documento bibliográfico. Trigésimo suplemento", Celestinesca (2006), 137-151.

Sesenta nuevas entradas de 2003-2006 agregadas a la creciente bibliografía celestinesca.

1965. PALAFOX, Eloísa, "Celestina y su retórica de seducción: comida, vino y amor en el texto de la Tragicomedia", Revista Canadiense de Estudios Hispánicos 32.1 (2007), 71-88.

Se analizan las alusiones e imágenes relacionadas con la comida, la bebida y el amor, con especial atención al auto noveno a la luz de la tradición occidental del banquete como ámbito retórico de la seducción de los sentidos y neutralización de la razón. Todos los personajes lo hacen, pero Celestina es quien se sirve de ellos con mayor sofisticación, contrastando la abundancia del pasado con la estrechez del presente (produce lástima), y aunando las relaciones entre comida y sexo (con la meta de neutralizar la demandas de los criados de repartir el botín). Irónico paso, siendo que su triunfo retórico sirve de antepuerta a su muerte.

1966. PAREDES, Ramón, «La comedia en la tragicomedia: el humor en La Celestina», (www.paredes.us/rojas.html).

Después de repasar lo poco que hay en la critica sobre el humor en Celestina (Lida de Malkiel, Ayllón, Gariano, Severin...), procede a dar ejemplos del humor situacional (lo de Crito, Pármeno hecho mozo de caballos, el cordón en manos de Calisto) y verbal (los apartes, la "cola de alacrán", la espada/pene como fuente del nombre 'Centurio' [Auto XviII]) y el sentido del humor de casi todo el elenco de personajes de la obra.

1967. PARKER, Mary, «Fernando de Rojas», en Spanish Dramatists of the Golden Age: A Bio-Bibliographical Sourcebook, ed. M. Parker (Westport CT: Greenwood, 1998), 145-176.

Más de veinte páginas de información sobre Rojas, su única obra (fuentes, la celestinesca posterior, influencias, ediciones, traducciones, etcétera) y una generosa selección bibliográfica. Un buen lugar para comenzar.

1968. PATTISON, David, "Aucto XVI of the Tragicomedia de Calisto y Melibea: A Route Back to Comedy?», Bulletin of Hispanic Studies 84 (2007), 545-552.

Melibea no se aprovecha de la disponibilidad de Pleberio de dejarle elegir a su esposo porque ella, tomando en serio la retórica del amor cortés como base de su vida, no acepta que el matrimonio con Calisto se puede concebir con final feliz 
1969. PATTISON, DAVID, "Is Celestina a medieval work?», en Late Medieval Spanish Studies in Honour of Dorothy Sherman Severin, ed. J. T. Snow \& R. Wright (Liverpool: Liverpool UP, 2009), 114-120.

The work is strikingly dependent upon medieval sources (including the humanistic comedies), morality, courtly love, use of exempla and sententious sayings, but what advances the work furthest into a new world are its use of irony and ambiguity.

1970. PEDRAZA JIMÉNEZ, Felipe B., "La Celestina y el teatro en la perspectiva del reinado de Isabel la Católica», en Arte y cultura en la época de Isabel la Católica, ed. J. Valdeón Baruque (Valladolid: Ámbito, 2003), 137-153.

Rojas es un dramaturgo culto y Celestina es drama. En un ambiente de artistas como Juan del Encina y Gil Vicente, Celestina es una obra excepcional, hasta un "error» (144), haciendo que simpaticemos con personajes despreciables. Es imitada en adaptaciones (ejemplos son: P. M. Ximénez de Urrea [1517] y el dramaturgo anónimo ingles de h. 1530) y prosistas (Feliciano de Silva, Sancho de Muñón....) pero sin ser superada en su inimitable uso del lenguaje.

1971. PELAÉZ BENÍTEZ, Ma Dolores, «Retórica y misoginia en la caracterización egoísta del héroe sentimental», Dicenda 21 (2003): 211-225.

Propone como posible antecedente del egoísmo de Calisto el del Aquiles, desarrollado en la versión castellana del Roman de Troie (1350). Aduce, además, en cada uno de los héroes sentimentales, el común empleo irónico de la "caída de los sabios», David, Salomón, etc. (Celestina, auto I).

1972. PÉREZ LÓPEZ, José Luis, «El converso Fernando de Rojas a la luz del expediente Palavesín», Bulletin of Hispanic Studies 83 (2006), 285-316.

Valora que el padre (Hernando) de Rojas fuera en 1488 declarado «judaizante» y que el nieto de Rojas dejó su pleito de probanza de hidalguía temiendo una resolución negativa, como ocurrió a sus parientes, los Franco. El expediente de Palavesín y un documento nuevo esparcen luz sobre la situación conversa de la familia Rojas en 1497, abandonando Toledo por La Puebla de Montalbán.

1973. PÉREZ PRIEGO, M. A., "Celestina y algunas representaciones teatrales en la Salamanca de Rojas», Theatralia 10 (2008), 77-88.

Reconociendo que en el ambiente universitario salmantino del siglo XV la importancia de las actividades orales en la vida de los estudiantes era sumamente importante, recoge información sobre las fiestas po- 
pulares, los espectáculos teatrales (Juan del Encina y Lucas Fernández, en particular) y encuentra ecos de todos ellos en el texto de Celestina. Representaciones sobre la muerte del príncipe Juan en 1497, espectáculos como el Diálogo entre el Viejo, el Amor y la Mujer hermosa, son obras que Rojas pudo haber presenciado y de las que pudo haber incorporado ecos en su texto casi contemporáneo.

1974. PÉREZ ROMERO, Antonio, "La Celestina and Inner Desire for Equality: The Search for Lasting Relationships as Existentialist Fulfillment", en The Subversive Tradition in Spanish Renaissance Writing) Lewisburg PA; Bucknell UP, 2005), 96-130; 252-285 (notes).

Las pp. 96-106 versan sobre las investigaciones modernas por su poca atención a los temas subversivos en la obra, y en particular Lida de Malkiel (1962) y Lacarra (1990). Mejor trato reciben Maravall (1976), Gerli (1999) y Dangler (2001). La segunda parte (pp. 96-130) nos lleva - acto por acto- por la obra al analizar los muchos temas subversivos presentes. Aunque Rojas apoya el status quo, los lectores podían captar bien los temas subversivos que recorren la obra.

a. Celestinesca 29 (2005), 259-261, E. Fernández.

1975. PUERTO, Laura, «La Celestina, ¿una obra para la postmodernidad? Parodia religiosa, humor, 'nihilismo'», Celestinesca 32 (2008), 245-264.

Predomina un cinismo en el uso del humor nihilista del autor de Celestina. La subversión, la ridiculización, la dinamitación (en fuertes parodias) de la religión, lo cortesano, y la mayoría de los personajes reflejan el inmenso pesimismo que se puede parangonar con la «era del vacio» posmoderno.

1976. QUIÑONERO HERNÁNDEZ, J. \& J. CALERO HERAS, Transición al Renacimiento: La Celestina (selección), Vademécum, 3, Barcelona: Octaedro, 2008 (1ª ed 1997). Rústica, 111pp. Ilustrado.

Una selección para alumnos del bachillerato, con páginas sobre la época y del autor (pp. 5-14) y el resto con estas secciones del texto: Carta, Versos Acrósticos, Prólogo, el auto I (dividido en dos), y los autos IV, X, XII, XIX y XXI. Cada sección tiene actividades, ilustraciones, citas de autores sobre la obra y notas en abundancia. Al final, hay unas actividades de síntesis.

1977. RANK, Jerry R., «Speculations about the Vanished Texts of the Celestina», en La Celestina 1499-1999, 189-196.

Una serie interesante de especulaciones sobre los manuscritos en circulación de Celestina, antes y después de su primera publicación. Es- 
pecula, tomando como referencia las sugerencias de M. Marciales, sobre la edad de Rojas al escribir la obra y posibles consecuencias para los investigadores y críticos de la obra. También especula sobre las denominadas «ediciones perdidas» necesarias para la reconstrucción de las stemmata (¿serían manuscritos? o ¡ediciones impresas?).

1978. RASCÓN PEÑAS, Ma Francisca, «El vestido en la literatura: La Celestina», en II Jornadas internacionales sobre moda y sociedad, ed. M. I. Montoya (Granada: Universidad, 2001), 305-309.

Los 33 términos relativos a la indumentaria femenina y masculina en la obra muestran diferencias de sexo, posición social, y hasta generacionales.

1979. RODRÍGUEZ CUADROS, Evangelina, "Retórica y dramaturgia del gesto y de la expresión en Celestina», Theatralia 10 (2008), 43-57.

Exploración pormenorizada (utiliza muchos ejemplos textuales) de la gestualidad, el ékfrasis y el retoricismo en la creación de una representación dinámica y viva, y de la dramaturgia de Celestina. Se demuestra cómo la obra es innovadora con respecto a sus modelos y cómo el ornatus sale de los márgenes para ocupar un lugar más central en su retórica y dramaturgia.

1980. RODRÍGUEZ-SOLÁS, David, "A la vanguardia del libro ilustrado: el terenciano de Lyon (1493) y La Celestina de Burgos (1499)», Bulletin of Spanish Studies 86.1 (2009), 1-17 (ilustrado).

La edición de Terencio de Lyon 1493 se compara favorablemente con la Comedia de Burgos en varias maneras; los dos impresores eran del valle del Rin, el estilo teatral (representación de escenas dobles, monólogos, etc.) de los grabados de las dos obras es semejante, sugiriendo que el artista de Burgos era también del valle del Rin, y Fadrique de Basilea conoció este Terencio, sin duda alguna.

1981. ROHLAND DE LANGBEHN, Regula, "La parodia en la novela castellana del siglo XV y en la Celestina», en Late Medieval Spanish Studies in Honour of Dorothy Sherman Severin, ed. J. T. Snow \& R. Wright (Liverpool: Liverpool UP, 2009), 86-94.

Es un artículo que pasa revista a puntos importantes del libro de Severin, Religious parody and the Spanish sentimental romance (2005), libro que hizo también varios comentarios valiosos de Celestina, aquí esbozados.

1982. ROJAS, F. de, La Celestina. Barcelona: Círculo de Amigos del Arte - Joyas del Editor: EDP Editores, 2007. Ilustraciones de Pablo Picasso. 
Se trata de una edición de gran lujo con 66 grabados firmados de Picasso procedentes de Valencia, en dos estuches. El texto es el de Valencia 1514, modernizado, acompañado de un tomo adicional con estudios.

1983. ROJAS, F. de, La Celestina. Ed. y prólogo de Emilio de Miguel. Biblioteca Castro, Madrid. Fundación José Antonio de Castro, 2006. Tela, 296pp.

La introducción, de unas 85 pp., refleja la sabiduría y aprecio de De Miguel a esta obra, aquí elegantemente editada por primera vez en la versión de Matías Gast (Salamanca 1570), con ilustraciones de la Comedia de Burgos, 1499. Útilmente divide en escenas los autos de la Tragicomedia, proceso iniciado por M. Marciales. Con un glosario y un índice de nombres. Una tirada de mil ejemplares numerados.

1984. ROJAS, F. de, La Celestina. Adaptación de Daniel Suárez Marzal. Publicaciones del Complejo Teatral de Buenos Aires, 33, Buenos Aires: Losada/Complejo Teatral de Buenos Aires, 2007. Rústica, 78pp. Ilustrado con fotografías.

El texto ocupa las pp. 31-69 en quince escenas. Se publican también dos reseñas y una entrevista con Suárez Marzal. Se estrenó el 31 de agosto de 2007 en el Teatro Regio del Complejo Teatral de Buenos Aires con, en Celestina, Elena Tasisto, en Melibea, Julieta Díaz, y en Calisto, Sergio Surraco.

a. Celestinesca 31 (2007): 187-189, Carina Zubillaga

1985. ROJAS, F. de, La Celestina, adaptación teatral de Jesús Torres. Ediciones del Orto, Madrid: Ed. Clásicas, 2009. Rústica, 62pp.

Introducción (8-12) de J. Torres, en el que explica algunas de las propuestas de su adaptación, obra en 29 escenas que exprime la esencia de la tragedia. La $1^{a}$ escena es un poema de J. Manrique ("El amor fuerza tan fuerte») y la última son los versos finales de Proaza, las dos escenas recitadas en coro por todos los actores.

1986. ROJAS. F. de, Celestina. Ed. Pedro M. Piñero. Guía de lectura Fernando Rayo y Gala Blanco. Austral Teatro 282, Madrid: Espasa, 2007. Rústica, 420pp. 1 ilustración.

La $43^{\text {a }}$ ed. y primera en esta presentación. Buena la introducción (965), el texto de la TCM con amplias notas (71-358), añadido por una básica guía de lectura (359-406) y un índice de notas (407-420). El glosario de términos va por categorías y en este formato es útil.

1987. ROJAS, F. de, La Celestina. Clásicos Literarios-Col. Didáctica, Madrid: McGraw-Hill-Interamericana, 2007. Rústica, 367pp. 
Ed. de Gerardo Diego, con una breve introducción general (7-37), seguida por la TCM modernizada con notas y avisos para el lectoralumno. Hay lecturas suplementarias y un brevísimo glosario.

1988. ROJAS, F. de, La Celestina. Colección Malva, Buenos Aires: Gradifico, 2007. Rústica, 255pp.

Una breve introducción sin firmar (3-8), seguido por el texto de la Tragicomedia y, en un apéndice, el Auto de Traso. Cubierta ilustrada en colores (Sevilla 1523); una edición sin notas, ilustraciones y bibliografía, destinada a la divulgación más básica.

1989. ROJAS, F. de, La Celestina. Col. Letras Mayúsculas, Madrid: Edimat, 2007. Rústica, 254pp.

Prólogo de Juan Alarcón Benito (5-20), una breve bibliografía con la fecha de 1965 la más reciente. Versión íntegra, modernizada, sin notas $\mathrm{y} \sin$ ilustraciones.

1990. ROJAS, F. de, La Celestina. Comedia o Tragicomedia de Calisto y Melibea. Ed. P. E. Russell. Clásicos Castalia, Madrid: Castalia, 2007. Rústica, 648pp.

Tercera ed., corregida y revisada. Con diez láminas en blanco y negro.

1991. ROJAS, F. de, La Celestina. Edición de A. Martín de Santa Olalla \& Begoña Pego. Leer en español, nivel 6, Salamanca: Santillana, 2008. Rústica, 98pp.

Segunda (la $1^{\mathrm{a}}$ en 1994) de esta Celestina adaptada en menos de 2.500 palabras. Con actividades para la mayor comprensión del texto.

1992. ROJAS, F. de, La Celestina. Col. Grandes Maestros 26, Barcelona: Artual, 1997. Rústica, 191pp.

Sólo el texto de la TCM, con pocas notas. Sin introducción, ilustraciones, bibliografía o prólogo.

1993. ROJAS, F. de, La Celestina. Prólogo de F. Rico. Ave Fénix Clásicos, Barcelona: Plaza y Janés, 1997. Rústica, 378pp.

Reproduce la que fue editada como parte de la Biblioteca de Plata de los Clásicos Españoles por la editorial Círculo de Lectores. Ensayo preliminar de Maite Cabello.

1994. ROJAS, F. de, La Celestina (con los cinco sentidos). Texto (adaptación) de Alfredo Gómez Cerdá. Ilustraciones de Teo Puebla y Sánchez Muñoz. Puebla de Montalbán: Ayuntamiento, 1999. 59pp. 
Para estudiantes de secundaria, con actividades (27-57). Es un relato sobre la obra clásica, en el que Fernando de Rojas es un personaje (1023). Una curiosidad.

1995. ROJAS, F. de, LC. Comedia o Tragicomedia de Calisto y Melibea, ed. $M^{a}$. Teresa Otal Piedrafita. Castalia Prima, La literatura para jóvenes, 42, Madrid: Castalia, 2006. Rustica, 322 pp.

Ilustrado. Después de una breve presentación (7-18), sigue el texto adaptado y, en parte, con algunos actos solamente resumidos (II, V, VIII, XIII, XV-XVIII). La acompaña (1) una Guía de lectura (269-284) y (2) unos Glosario de palabras y de refranes (285-318). Como está preparada para jóvenes, lleva unos 950 notas.

1996. ROJAS, F. de, La Celestina. Ed. de Julio Rodríguez-Púertolas, con una introducción de Juan Goytisolo y 36 luminosas ilustraciones en color de Teo Pueblo. La Puebla de Montalbán, 2005. Gran formato, 331pp.

Reimpresión de la edición que se preparó para la celebración del quintocentenario en 1999.

1997. ROJAS, F. de, La Celestina. Ed. de Julio Rodríguez-Puértolas. Prólogo de Juan Goytisolo (13-29), ilustraciones de Teo Puebla, Introducción (33-38) y Epílogo (353-76) de J. R.-P. La Puebla de Montalbán: Ayuntamiento, 2008. Tela, 389pp.

En nuevo formato, con una cronología al final y con ilustraciones de Teo Puebla, comisionadas para el quinto centenario de 1999.

1998. ROJAS, F. de, La Celestina. Ed. D: S. Severin, notas en colaboración con Maite Cabello. Letras Hispánicas 4, Madrid: Cátedra, 2008. Rústica, 358pp.

Es la $17^{a}$ edición de esta clásica edición, de amplia distribución y uso.

1999. ROJAS, F. de, La Celestina. Biblioteca Universal - Clásicos Españoles, Barcelona: Círculo de Lectores, 1999. Tela, 368pp.

Edición de Guido M. Capelli y de Gema Vallín, con un Prólogo ( «La técnica dramática de La Celestina») de M. R. Lida de Malkiel (11-27). E1 «Pórtico» es firmado por Francisco Rico, director de la Colección. La introducción es de Capelli (29-52) y la «Nota sobre el texto y la bibliografía básica» de ambos editores (53-58). Contiene toda la TCM, con extensas notas. Sin ilustraciones.

2000. ROJAS, F. de, La Celestina. Adaptación de Eduardo Alonso e ilustraciones de Francisco Solé y Fuencisla del Amo. Clásicos adaptados 13, Barcelona: Vicens Vives, 2007. Rústica, 249pp. Ilustrado- 
De formato grande, con una introducción de Antonio Rey Hazas y «Actividades» diseñadas por Gabriel Casas. Contiene dos terceras partes del texto, las reducciones no reducen los 21 actos, solo que cortan prolijidades y, además, los versos acrósticos al comienzo y los versos de Proaza al final. El papel fino que se usa luce bien las prolíficas ilustraciones, fotos, y cuadros originales de los dos ilustradores. Algunos en blanco y negro, la mayoría en color.

2001. ROJAS, F. de. La Celestina. Adaptación de Eduardo Alonso. Clásicos adaptados, 13, Barcelona: Vicens Vives, 2007. Rústica, 249pp. Con ilustraciones de F. Solé y F. del Amo.

La introducción es, según el (C), de Antonio Rey Hazas, pero la firma E. Alonso. El texto se reduce un tercio (y omite los acrósticos y las octavas finales). Texto modernizado, con notas, pero sin bibliografía. Hay al final unas "Actividades» preparadas por Gabriel Casas

2002. ROJAS, F. de, La Celestina. TCM. Prólogo, selección de refranes y glosario de Francisco Calero. Ilustraciones de Ángel Roncero. Madrid: BBVA, 2005. Tela y gran formato, 98 folios (=198pp).

El prólogo está ilustrado con grabados sacados de ediciones de Celestina. El texto está en letra gótica de doble columna y presentado como si fuera un manuscrito con los márgenes llenos de flores, frutas, ángeles. Una edición en formato de libro de mesa de centro, para bibliófilos.

2005. ROJAS, F. de, La Celestina. Ed. Manuel Criado de Val y J. Alcina Franch. Ilustraciones de J. Azpelicueta. Barcelona: Juventud, 2008. Rústica, 238pp.

La $4^{a}$ edición de esta TCM.

2006. ROJAS, F. de, La Celestina, adaptación para estudiantes de Rosa Navarro Durán. Clásicos para estudiantes, Barcelona: EDEBÉ, 2008. Rústica, 299pp. Ilustraciones de Carles Arbat.

La TCM modernizada y en letra grande (9-268). Breve estudio (271279) y actividades para los estudiantes (281-299).

2007. ROJAS, F. de, La Celestina, ed. introducción, notas y actividades de Francisco Bautista. Clásicos edebé, Barcelona: EDEBÉ, 2008. Rústica, 350pp.

Introducción (12-42), texto de la TCM y generosas notas léxicas al margen; las actividades (323-350) con la colaboración de Laura Mier. No hay ilustraciones o bibliografía. 
2008. ROJAS, F. de, La Celestina. Adaptación de Antonio Perera Sarmiento (fotos ilustraciones) y Miguel A. Perera Alonso. Madrid: Témpora, 2002.

Versión en formato de cómic.

2009. ROJAS, F. de, La Celestina. TCM. Barcelona: Folio, 2002. Tela, 254pp.

Con una breve nota de D. S. Severin como introducción. Modernizada la edición para el gran público. Hay notas y un cuadro cronológico al final. Sin ilustraciones

2010. ROJAS, F. de, La Celestina. TCM. Valladolid: MAXTOR, 2007. Rústica, 376pp.

Formato pequeño. Contiene toda la TCM y un vocabulario al final. No hay introducción, ilustraciones, bibliografía o notas. Modernizada, evidentemente, para lectores sin otro interés que el texto.

2011. ROJAS, F. de, La Celestina. Introducción y notas de Pier Luigi Crovetto, traducción al italiano de Viviana Brichetti. Milano: Garzanti, 2004.

2012. ROJAS, F. de, Celestyna. Traducido del español al polonés por Barbara Sławomirska. Sagittarius, 2000. Rústica, 198pp.

La traducción emplea las ilustraciones de Burgos 1499. Contiene al inicio los versos acrósticos pero no incluye introducción ni notas.

2013. ROJAS, F. de, La Celestina, traducción libre al coreano por Ahn Young Oak. Seúl: Chanyewon, 2006. Rústica, 191pp.

Texto adaptado, con una introducción, lista de personajes, pero sin notas, ilustraciones o bibliografía.

2014. ROJAS, F. de, La Celestina, traducida al árabe. Beirut: Resalah Publishers, 2005. Rústica, 98pp.

2015. ROJAS, F. de, y antiguo autor, Selestina. Belgrado: Paideia, 2005. Tela, 205pp.

Esta traducción al serbo-croata es de Aleksandar Grujičič. Es la TCM completa, con algunas notas. Sin ilustraciones; hay un pos-facio y una bibliografía con 4 entradas (p. 205)!

2016. ROJAS, F. de, La Celestina. Bratislava: Remedium, 1996. Tela, 264pp.

La TCM completa traducida al checo-eslovaco por Vladimír Oleríny. Con 311 notas explicativas al final de la edición. Sin ilustraciones 
2017. ROJAS, F. de, La Célestina, traducida al francés por Aline Schulman. Introducciones de Juan Goytisolo y Carlos Fuentes. Paris: Fayard, 2006.

2018. ROJAS F. de, Celestina. Traducida por Hristina Vasileva. Sofía (Bulgaria): Ispanska klasika, Hispanica, 2007. Rústica, 111pp.

Esta obra es una traducción en 16 autos sin los pre-y posliminares. No hay introducción, notas, bibliografía o ilustraciones.

2019. ROJAS, F. de, La Celestina. Texto adaptado por Fran Zabaleta. Ilustraciones de Juan Ramón Alonso. Madrid: Grupo SM, 2008. Rústica, $111 \mathrm{pp}$.

Una adaptación abreviada, con muchas didascalias, en catorce actos, que retiene la esencia del texto, eliminando los largos diálogos y la presencia de Crito. Los otros 13 personajes siguen. Termina con un párrafo del lamento de Pleberio, pero finaliza con la expresión «en este valle de lágrimas». Profusamente ilustrada.

2020. ROJAS; F. de, La Celestina. Adaptación de Miguel Reino. Col. Leer en Español. Nivel 6, Torrelaguna (Madrid): Santillana Educación/Universidad de Salamanca, 2008. Rústica, 98 pp. Ilustrado por Jorge Fabián González en color.

Para estudiantes, una puesta al día de la ed. de 1994. El texto, modernizado y condensado en 5 Partes y varias escenas. Con actividades para comprender la obra y unas notas explicativas (88-98).

2021. RUANO DE LA HAZA, José María, «Una adaptación de la Tragedia de Calisto y Melibea, llamada Celestina», Theatralia 10 (2008), 151-161.

Historia de cómo llegó Ruano de la Haza a adaptar Celestina y la manera cómo lo hizo, contada por él mismo. Confiesa que es sólo una de las Celestinas que la obra original puede contener, centrada en Melibea.

2022. RUANO DE LA HAZA, José María, Celestina. Versión y adaptación libre de J. M. Ruano de la Haza. Theatralia 10 (2008): 165-217. Con 8 fotos de dos distintas producciones de la obra.

Se presenta el texto de la adaptación y los elencos de sus primeras representaciones (Almería, Santiago de Chile). La obra contiene 16 escenas. Comienza y termina con voz en off el abreviado monólogo de Pleberio que lamenta la tragedia de su hija, haciendo que sea una visión circular de las acciones centrales de esta adaptación. Ver también el art. de A. Hermenegildo (arriba). 
2023. RUIZ IPOLA, Pablo, Desnudando a Melibea. Móstoles (Madrid): A la luz del candil, 2005. Rústica, 80pp.

Poemas. Sin introducción para explicar la selección del título y las posibles conexiones con la obra clásica.

2024. RUIZ MONEVA, $M^{a}$ Ángeles, "Aproximación a una versión inglesa de La Celestina», en Teatro Clásico en Traducción. Teatro. Representación. Recepción. (Murcia: Universidad, 1996), 353-361.

Compara la Celestina española con una traducción parcial al inglés de hacia 1539 (A New Comedy in English in Manner of an Interlude, Calisto and Melebea [sic]) para mostrar claramente cómo el mensaje didáctico se transforma en esta adaptación renacentista y cómo se adapta a las normas de la tradición inglesa del desenlace a través del sueño.

2025. SALUS, Carol, «Some Early Celestina Drawings by Picasso», Celestinesca 30 (2006), 11-123.

Picasso pintó figuras inspiradas en Celestina en los años primeros y finales de su carrera. Se esbozan brevemente las posibles causas de esta fijación, después se indagan sus orígenes (en revistas como Blanco y Negro y Teatro Crítico, y en su seguimiento de los pasos de Goya y sus celestinas). Por último, se analizan en detalle dos pinturas, El diván y El harén, llegando a la conclusión que la vieja de este último cuadro no es una celestina sino una asistente de los baños, por no estar en el negocio de la prostitución (no es proxeneta) y por carecer de los patrones iconográficos de otras versiones

2026. SALVATERRA, Julio (texto) y Álvaro LAVIN (actor, Calisto). Monólogo teatral de una hora, presentado por la Compañía del Teatro Meridional en 1998. Visto en Lyon, Francia en mayo de 2008.

Monólogo unipersonal en el que Calisto rememora sus más de 500 años de existencia en 24 voces/personajes, pasando por la España de Rojas a las obras shakespearianas en una serie de anécdotas cómicas y trágicas. Se presencia en este tour de force el nacimiento de un hombre y una sociedad moderna en pleno siglo xvI.

2027. SANMARTÍN BASTIDA, Rebeca, «Sobre el teatro de la muerte en La Celestina: el cuerpo 'hecho pedazos' y la ambigüedad macabra", eHumanista. Journal of Iberian Studies 5 (2005), 113-125.

S.B. encuentra las claves de la moralidad de Celestina, más que en el discurso de Pleberio al final, en la presentación de los cadáveres de los cinco personajes que mueren antes, el «teatro de la muerte» en el que se inscriben temas como lo macabro, el voyeurismo, el castigo del he- 
donismo que restaura orden, etc. Las metáforas funestas de la literatura sentimental se hacen en Celestina realidades, por lo que puede verse como un sermón macabro en una cultura entregada a la culpabilidad y penitencia.

2028. SCARBOROUGH, Connie L., "Las mujeres de Celestina: realidades sociales e inquietudes literarias", en Anais, IV Encontro Internacional de Estudos Medievais (Belo Horizonte: Pontificia Univ. de Minas Gerais / Assoc. Brasileira de Estudos Medievais, 2003), 81-98.

After a general overall panorama, the female characters are discussed one by one as social beings and literary mouthpieces.

2029. SCARBOROUGH, Connie L., "Celestina and the Power of Old Age", in Old Age in the Middle Ages and the Renaissance. Interdisciplinary Approaches to a Neglected Topic, ed. A. Classen (Fundamentals of Early and Modern Culture 2, Berlin/New York: Walter de Gruyter, 2007), 343-56.

The main point is that Celestina breaks away from her assumed marginality, becomes individualized and central to the plot. She exploits her age time and again to gain sympathy, to lower the guard of the watchful, to negotiate a society fraught with self-interest, greed and lust, but ends by playing the "age» card once too often and it backfires and she ends up assassinated. Though a sympathetic figure, her desire to remain central to the lives of others undoes her and her private notions about age and loss (act IX) come to pass.

2030. SCHULMAN, Aline, "Traduire La Célestine aujourd'hui», Celestinesca 32 (2008), 279-290.

La traductora (2006) de Celestina al francés explica varias estrategias utilizadas en su re-traducción para captar de nuevo la legibilidad (tempo, sintaxis, trato social, etc.) del original para un público 500 años después con ilustraciones de cada concepto y algunas traducciones suyas comparadas con las de Pierre Heugas (1963).

2031. SERÉS, Guillermo, "Menéndez Pelayo y La Celestina», en "Orígenes de la novela» Estudios, dir. R. Gutiérrez Sebastián \& B. Rodríguez Gutiérrez (Santander: Universidad de Cantabria/Sociedad Menéndez Pelayo, 2007), pp. 381-405.

Repasa los principales motivos comentados por el polígrafo santanderino en su estudio de Celestina de 1910 (el humanismo, la autoría, el género, las fuentes, los personajes, le lengua y el decoro) y agrega apuntes sobre lo que han hecho selectos investigadores modernos para adicionar, corregir, o ampliar sus comentarios. Su bibliografía está ahora incorporada en una más general para el tomo completo. 
2032. SERRANO, Florence, "La Celestina en la Francia del Renacimiento y del Siglo de Oro: texto y contexto, difusión y fortuna», Celestinesca 32 (2008), 265-278.

Nace el interés por Celestina en Francia con la traducción de Sylvia nuptialis de Nevizzano (1521), y hay tres traducciones con varias ediciones entre 1527 y 1633, todas ellas analizadas y comentadas aquí. La primera y anónima $(1527,1529$ y 1542) sirve para difundir la obra, la segunda $(1578,1584,1599)$, traducida por Jacques de Lavardin, enfatiza el elemento didáctico, y la tercera (1633), también anónima y publicada en una edición bilingüe, es la más fiel y refleja las buenas relaciones editoriales entre los dos países.

2033. SEVERIN, Dorothy S., "Celestina's audience, from manuscript to print», en La Celestina 1499-1999, 197-205.

Compara lecturas y correcciones al manuscrito de Palacio que prueban con toda probabilidad que era un texto circulado en Salamanca, y corregido por la mano de un lector (¿amigo del autor?) interesado en mejorar la copia. No parece ser el manuscrito usado por el impresor de la Comedia.

2034. SEVERIN, Dorothy S., "Witchcraft in Celestina: A Bibliographical Update since 1995", La corónica 36.1 (2007-2008), 237-43.

Un panorama completo de lo publicado sobre la magia en Celestina en los últimos 12 años, con comentarios sobre las distintas categorías y enfoques de los estudios.

2035. SNOW, Joseph T., "Celestina Examined: A View from the Sixteenth Century», La corónica 33.1 (2004-2005), 181-196.

Artículo-reseña de la Celestina Comentada (Salamanca 2002), primera edición de este texto sobre la recepción de la obra clásica escrito h. 1575 .

2036. SNOW, Joseph T., "Lo teatral en Celestina: el caso de Areúsa», en La Celestina 1499-1999, 207-217.

Entendiendo lo teatral como teatralidad y no en relación al debate sobre el género de la obra, se presenta a Celestina como maestra del arte histriónico, aspecto requerido por su profesión y forma de vida. No obstante, el estudio se centra en la Areúsa de la Tragicomedia, cuyas dotes dramáticas resultan claves para la cadena de reacciones que llevan al desastrado fin. La comparación de su arte con la de Celestina (auto XVII) lleva a una distinta relectura del auto VII, y a preguntarse frente a la interpretación crítica tradicional de la escena (la persuasión de Areúsa 
por Celestina), ¿quién está manipulando a quién? Areúsa, sin la sospecha de Celestina, se cuenta entre las maestras del oficio y, después de la muerte de Celestina, se erige en rival retrospectiva con entidad y como heredera, reclamando incluso la superioridad de su arte.

2037. SNOW, Joseph T., "La Brígida de José Zorrilla y su celestinaje», Revista canadiense de estudios hispánicos 32.1 (2007), 137-148.

La reedición en 1822 de Celestina es responsable de su popularidad entre 1820-1840; será un factor decisivo en la incorporación de Brígida en el Don Juan Tenorio de Zorrilla, frente al Burlador de Tirso. Se analizan las similitudes de Celestina y Brígida desde las perspectivas de caracterización, estructura, función, simbolismo, y retórica. Aun así, Brígida presenta grandes diferencias con su antecesora (no tiene pasado ni otros oficios ni la complejidad sicológica) y su poder retórico aparece supeditado al más efectivo del amante (escrito y oral).

2038. SNOW, Joseph T., y Arno GIMBER, «Richard Strauss, Stefan Zweig, Joseph Gregor and the Story of the Celestina Opera that Almost Was, with a Bibliographical Appendix of Celestina Operas in the Twentieth Century», Celestinesca 31 (2007): 133-164.

El año de 1936 en plena época de Hitler, será cuando Zweig, Gregor y Strauss trabajaron en una ópera basada en Celestina, ópera destinada a no realizarse musicalmente. Se reconstruye esta historia casi desconocida a base de las cartas intercambiadas entre los tres y se publica en traducción inglesa el plan que hizo Gregor para Strauss para los tres actos de la ópera. Un apéndice resalta el interés en las óperas basadas en Celestina en el siglo Xx.

2039. SNOW, Joseph T., "La Celestina: grupo ROR de la Universidad Complutense. Dirección y dramaturgia de David Barrocal», Theatralia 10 (2008), 105-132.

Ilustrado con seis fotos de esta nueva adaptación, el artículo sigue paso por paso la dramaturgia (y dirección) de Barrocal de esta Celestina, comparando y contrastándola con el texto canónico para realzar la originalidad lograda en una adaptación concentrada en el Carpe diem en la que se prescinde de cualquier mensaje didáctico-moral. Una adaptación digna de verse representada en más ocasiones.

2040. SNOW, Joseph T., "La Celestina de David Barrocal en la Complutense», Celestinesca 31 (2007), 177-181.

Una reseña pormenorizada e ilustrada de esta representación que señala su originalidad de concepto y efectos conseguidos. 
2041. SNOW, Joseph T., "Las tres primas del entorno celestinesco y una nota sobre el tema del linaje», Celestinesca 32 (2008), 291-306.

Se estudia la biografía de cada una de las primas, rastreando el texto con lupa y descubriendo hasta el pasado de las tres relaciones familiares. Luego las estudia por parejas para reflejar la especial atención textual prestada a su parentesco. Este énfasis es quizá irónico a la luz de lo que afirma Areúsa «las obras hazen linaje» y en presencia del comportamiento de los que sabemos gozan de gran prestigio e influencia social

2042. SNOW, Joseph T., «El pre-texto celestinesco: posibilidades interpretativas", en Actas del XI Congreso Internacional de la Asociación Hispánica de Literatura Medieval (León, 20-24 de septiembre de 2005) (eds. A. López Castro - L. Cuesta Torre), León: Universidad, 2007, vol. II: 1047-1054.

S. reconstruye a partir de referencias textuales (y por deducción) los eventos en los 75 años (analizados por cuartos de siglos) antes del comienzo del texto que ayudan a dar profundidad y verosimilitud a la historia de los conflictos que se realizan a lo largo de Celestina.

2043. SNOW, Joseph T., "Celestina's houses», en Late Medieval Spanish Studies in Honour of Dorothy Sherman Severin, ed. J. T. Snow \& R. Wright (Liverpool: Liverpool UP, 2009), 133-142.

Es un intento de sugerir que el texto da muchas probabilidades realistas de ir poblando la ciudad dominada por Celestina. No sólo habla de las casas de las personas que hablan en la obra, sino va perfilando la ciudad y sus barrios según las menciones de lugares, oficios, y personajes en boca de los que dialogan, como si pudieran trazar un plan de la geografía de Celestina.

2044. SOLANA SEGURA, Carmen, "Casandrina vs. Roselia. Dos modelos de enamoradas celestinescas», Lemir 12 (2008), 19-30.

Separan estas dos obras celestinescas casi medio siglo: Roselia (1542) y Casandrina (h. 1600). Mientras la primera es la más fiel a la obra original, la segunda crea distorsiones en los paradigmas celestinescos y se parece más a los cánones de las nuevas pícaras como la Ingeniosa Elena. Lisandro y Roselia son de la aristocracia, mientras en al segunda Polidoro es un mercader rico y Casandrina es hija de la alcahueta Corneja. El conjuro en la segunda afecta al protagonista, y la agresora en las relaciones sexuales es Casandrina. El hermano de Roselia mata a los amantes por sentirse deshonrado, mientras Polidoro y sus criados son muertos mediante trucos de Fortuna y las tres Parcas, mientras Corneja y Casandrina se escapan con la riqueza del amante muerto. 
2045. SOLOMON, Michael, "Pharmaceutical Fictions: Celestina's Laboratory and the Sixteenth-Century Medical Imaginary", en Medieval Iberia. Changing Societies and Cultures in Contact and Transition, ed. Ivy A. Corfis \& Ray Harris-Northall (Woodridge, UK: Támesis, 2007), 99-109.

Se centra en el intento de Pármeno para desviar a Calisto de utilizar los servicios de Celestina (auto I), al catalogar su laboratorio farmaceutico. Al contrario, Calisto ve en esta denigración su más seguro remedio. Solomon usa este episodio para comentar el estado social de estas mujeres en la sociedad del siglo XV que va evolucionando hacia un riguroso establecimiento de normas profesiones bajo control de los practicantes licenciados (hombres).

2046. SUÁREZ COALLA, Francisca, "La función de los apartes en el discurso dialógico de La Celestina», Archivum 39-40 (1989-1990), 469-484.

Según este estudio breve, los apartes entre criado-amo y criado-criado varían. Hay unos que claramente intentan burlarse del otro y hay otros que revelan el verdadero personaje del actante e introduce claves interpretativas de doble sentido. Entre los criados, a veces hay intentos de comunicación pero lo que se revela a través de los apartes es el espíritu individualista de cada uno de los dialogantes.

2047. TEATRO: La revista del complejo teatral de la Ciudad de Buenos Aires. Vol. 28, núm. 92 (sept. 2007), 4-37.

Un número que trae varios artículos referentes a la representación de Celestina, en versión de D. Suárez Marzal. Da una visión de Europa y España en época de Celestina Luis Gregorich (4-9); ofrece Pablo Lettieri en "tras las huellas de un converso" (10-11) datos sobre la vida y carrera de F. de Rojas; Jorge Monteleone en "La incesante discordia del deseo» (12-21) aporta un ensayo erudito sobre la relevancia de Celestina en nuestros tiempos; Ariel Dillon entrevista al director, Suárez Marzal en «El amor, la fortuna y la muerte» (22-29); Pablo Lettieri saca las impresiones de Elena Tasisto que debutó en Celestina (30-31); Jorge Grubissich habla de la música de esta representación en «Viaje al pasado con laúd y contratenores» (32-35); y Mariano Ríos comenta la escenografía y vestuario en "Espacios virtuales y trajes sin tiempo» (36-37). Todo ilustrado con fotografías de la producción.

2048. TWOMEY, Lesley K., "Perfume and perfume-making in the $\mathrm{Ce}$ lestina», en Late Medieval Spanish Studies in Honour of Dorothy Sherman Severin, ed. J. T. Snow \& R. Wright (Liverpool: Liverpool UP, 2009), 143-149.

An interesting review of those elements in Pármeno's speech from auto I relating to Celestina's perfumes, including analyses of items men- 
tioned, their social uses, and their occasional falsification. Not only is it suggested that the art was associated with marginalized women, but it is clear from some of the containers employed that Celestina retains some from an earlier, more prosperous past.

2049. UNCETA, María, Rutas turísticas literarias. Un autor para un viaje: Fernando de Rojas. Consejería de Turismo de Castilla-La Mancha, 2008. Rústica, 120pp. Ilustrado.

En la biografía de Rojas (9-12) se nota la falta de documentación, excepto en Talavera. Las pp. 19-65 son textos de la adaptación teatral de 1999 de Luis García Montero. En las pp. 67-113 se exploran los lugares de Rojas (la ruta turística): La Puebla de Montalbán, Talavera de la Reina y otros pueblos cercanos. Termina (115-20) con datos prácticos sobre alojamiento y restaurantes.

2050. VALLE DE RICOTE, Gofredo, Investigaciones en Blanca. Los tres autores de la Celestina: El judeo-converso Juan Ramirez de Lucena, sus hijos Fernando de Rojas (Lucena) y Juan del Encina (alias Bartolomé Torres Naharro y Francisco Delicado). Tomo I. Biografía, estudio y documentos del antiguo autor de 'La Celestina', el ajedrecista Juan Ramírez de Lucena. Blanca (Murcia): Academia de Estudios Humanísticos de Blanca, 2006. xviii + 441pp.

En este primer tomo, con otros 4 o 5 en preparación, el autor (Gofredo Westerveld, escribiendo con seudónimo) dedica su estudio y documentos al primero de los proyectados tres autores de Celestina: Juan Ramírez de Lucena, el protonotario y sus escritos, su familia, y otras familias Lucena. Presenta un "estado de la cuestión» en el que al autor propone que faltan muchos documentos todavía por conocer.

2051. VAQUER, Onofre, "Llibres i retaules en cases mallorquines (segle xVI, segona meitat)", Mayurqa 31 (2006), 295-323.

Un documento que confirma, sobre 355 libros conservados en Mallorca, un ejemplar de Celestina.

2052. VARIOS AUTORES, La Celestina. Mérida: De la Luna Libros, 2007. Rustica, 62pp.

Es el número 18 de La luna de Mérida (una revista de creación) que consiste en siete monólogos o diálogos breves, compuestos por autores distintos, inspirados en Celestina. La voz del Prologo es de Fernando de Rojas. Le siguen monólogos de Areúsa, Celestina, y un diálogo con Celestina, Melibea y Calisto, un monólogo de Melibea y un dueto con Calisto y Melibea. Estos seis forman, en lengua moderna pero reminiscente de la del texto celestinesco, un resumen de las acciones 
amorosas. El último diálogo, entre dos mellizos, es más tangencial a la obra clásica, aunque inspirado en ella.

2053. VASVARI, Louise O., "Escolios para el vocabu(r)alrio de La Celestina», en La Celestina 1499-1999, 219-233.

Se centra en selectos "dichos lascivos» del primer auto de Celestina (en la sección del diálogo entre Celestina y Pármeno), trayendo a cuenta la larga tradición que respalda cada uno de ellos ("putico,» "voz ronca,» «punta de la barriga,» $\mathrm{y}$ "cola de alacrán», y «landrecilla,» entre otros).

2054. VASVARI, Louise O., "Glosses on the vocabu(r)lario de La Celestina", en Late Medieval Spanish Studies in Honour of Dorothy Sherman Severin, ed. J. T. Snow \& R. Wright (Liverpool: Liverpool UP, 2009), 170-181. Ilustrado.

Es una exploración folklórica del significado obsceno creado en la ambigüedad lingüística del «dolor de muelas» fingido de Calisto (Auto IV) y las negociaciones entre Celestina y Melibea sobre el subtexto sexual-erótico. Estas relexicalizaciones eufemísticas son compartidas, como se demuestra aquí, casi universalmente en la literatura oral y en el folklore.

2055. VON DER WALDE MOHENO, Lillian, «El cuerpo de Celestina: un estudio sobre fisonomía personalidad», eHumanista 9 (2007), 129-142.

Un estudio que explora la relación entre el aspecto corporal externo de Celestina y su condición moral abyecta. La Edad Media heredó de la Antigüedad la creencia de que los vicios y virtudes se hacían reconocibles mediante las formas del cuerpo. El artículo analiza al detalle la descripción física del personaje — barbuda, cuchillada, vieja, desdentada (...) - y su simbolismo moral en la tradición culta y popular, con el apoyo textual de obras como el Tratado de phisonomía, el Libro de las donas, el Tratado de fascinación o aojamiento o el Lilium medicinae. La relación: fealdad física y fealdad moral, sería un indicio de cómo los receptores de su tiempo interpretaron a la alcahueta, mientras que el hecho de que el resto de los personajes se relacionen con ella revelaría la corrupción del mundo celestinesco (RA).

2056. VIVANCO, Laura, Death in Fifteenth-Century Castile: Ideologies of the Elites. Colección Tamesis, Seria A, Monografías 205, Woodbridge, UK: Tamesis, 2004.

En las pp. 108-121 ("God and the Devil») se presenta una visión esencial medieval de las creencias sobre Dios y el Diablo en Celestina. La autora sigue la pauta mágica de Russell, Deyermond, Severin y Haywood al asociar Celestina y su comportamiento con el diablo, pero 
aporta nuevas revelaciones en cuanto las asociaciones de otros personajes (Calisto y Sempronio) con las maquinaciones del poder maléfico.

2057. «Watermarks from Celestina 1499», en La Celestina 1499-1999, 325335.

Figura como un apéndice. Sacadas estas filigranas de negativos preparados en los años 50 para el trabajo de Clara Luisa Penney (The Book Called Celestina in the Library of The Hispanic Society of America). Hay un total de once en este apéndice.

2058. WEISS, Julian, «Memory in creation: the context of Rojas's literary recollection", en Late Medieval Spanish Studies in Honour of Dorothy Sherman Severin, ed. J. T. Snow \& R. Wright (Liverpool: Liverpool UP, 2009), 150-158.

Rojas, Diego de San Pedro (Cárcel de amor) y Rodríguez de Montalvo (Amadis de Gaula) comparten el uso de la memoria y creatividad (manifiesto en el recordar y el olvidar) en los retratos que dejan de sí mismos en sus obras. Central a esta exposición son la lectura, memoria y la invención literaria, en su conjunto un proceso de descubrimiento.

2059. WHINNOM, Keith, The textual history and authorship of 'Celestina'. Ed. Jeremy Lawrance, Papers of the Medieval Hispanic Research Seminar, 52, London: Queen Mary-Univ. of London, 2007. Rustica, 104pp.

En el prefacio del libro, A. Deyermond narra la historia de este texto. La lúcida introducción de Lawrence detalla como el manuscrito inédito (e incompleto) de Whinnom ha sido editado. La parte de Whinnom presenta claramente la historia textual de las tres Comedias, cotejándolas para demostrar sus diferencias de contenido (32-58). Hace lo mismo para las tempranas formas de la Tragicomedia (59-86), y presenta algunas conclusiones de sus consideraciones (87-90). Define los problemas de la historia textual e intenta aclarar las dudas sobre autoría (KW no duda que Rojas es el autor de autos 2-21), a la vez que ofrece esclarecimientos sobre el papel del corrector Proaza en la historia textual de Celestina. 